\title{
Multiscale Characterization of the Caney Shale - An Emerging Play in Oklahoma
}

Yulun Wang1(yulun.wang@okstate.edu), Guofan Luo² (luogf880831@gmail.com), Mercy Achang² (mercy.achang@okstate.edu), Julie Cains¹ (jcains@okstate.edu), Conn Wethington ${ }^{1}$ (conn.wethington@okstate.edu), Allan Katende ${ }^{2}$ (allan.katende@okstate.edu), G. Michael Grammer ${ }^{1}$ (michael.grammer@okstate.edu), Jim Puckette ${ }^{1}$ (jim.puckette@okstate.edu), Jack Pashin ${ }^{1}$ (jack.pashin@okstate.edu), Marc Castagna ${ }^{3}$ (marc.castagna@thermofisher.com), Han Chan ${ }^{3}$ (han.chan@thermofisher.com), George E. King (gkingengineering@gmail.com), and Mileva Radonjic $c^{5,2,1}$ (mileva.radonjic@okstate.edu)

${ }^{1}$ Boone Pickens School of Geology, Oklahoma State University

${ }^{2}$ School of Chemical Engineering, Oklahoma State University

${ }^{3}$ Thermo Fisher Scientific

${ }^{4}$ GEK Engineering

${ }^{5}$ corresponding author

\begin{abstract}
From a hydrocarbon perspective, the Caney Shale has historically been evaluated as a sealing unit, which resulted in limited studies characterizing the rock properties of the Caney Shale and its suitability for hydraulic fracturing. The objective of our research is to help bridge the current knowledge gap through the integration of multiscale laboratory techniques and to characterize the macro- and microscale rock properties of the Caney Shale. We employed an integrated approach for the characterization of the Caney using $200 \mathrm{ft}(61 \mathrm{~m})$ of Caney core from a target well in southern Oklahoma. Core observation and petrographic analysis of thin sections were combined to characterize the general rock types and associated fabrics and textures. Mineralogical composition, pore system architecture, and rock fabric were analyzed using x-ray diffraction (XRD), scanning electron microscopy / energy dispersive $x$-ray spectroscopy (SEM/EDS), and focused ion beam (FIB)SEM. In addition, rebound hardness and indentation testing were carried out to determine rock hardness (brittleness) and elasticity, respectively. With the integrated multiscale characterization, three mixed carbonate-siliciclastic rock types were identified - mudstone, calcareous siltstone, and silty carbonate - likely representing a spectrum of deposition from low to relatively high energy environments in the distal portions of a ramp system. Silty carbonate contains mostly interparticle pores. The calcareous siltstones and silty mudstones contain a combination of organic matter pores and interparticle pores. Each of the rock types shows unique mineralogical compositions based on XRD. The mudstone lithofacies has the highest clay content and the least carbonate content. Calcareous siltstones show moderate carbonate and clay content. Silty carbonate indicates the highest carbonate content with the least clay content. In an order of mudstone, calcareous siltstone, and silty carbonate, rebound hardness and Young's modulus show an increasing trend. As a result of rock-fluid interactions, there are potential scaling reactions during completion and production
\end{abstract}

\section{Midcontinent Geoscience • Volume 2 • September 2021}

Midcontinent Geoscience is an open-access, peer-reviewed journal of the Kansas Geological Survey. The journal publishes original research on a broad array of geoscience topics, with an emphasis on the midcontinent region of the United States, including the Great Plains and Central Lowland provinces. 
that could ultimately affect permeability and production rates. Overall, the proposed multiscale integration approach is critical for the geologic characterization of most rocks. However, in shale reservoirs dominated by microporosity and microstructure where engineered fractures are expected to provide permeability at a reservoir scale, successful integration is essential. An optimized, integrated geological characterization of the Caney Shale that is well aligned with the engineering designs in drilling, completing, and producing wellbores will ultimately lead to optimal production while providing safe and environmentally responsible operations.

\section{INTRODUCTION}

To achieve an integrated characterization of unconventional "shale" reservoirs, geological observations and data across the macro to nanometer scale are essential. Macroscopic features can include facies and their vertical stacking patterns (i.e., stratigraphy) and structural patterns, whereas key mesoscopic factors include bedding, physical and biogenic sedimentary structures, and natural fractures (e.g., Wang et al., 2019). Microscopic and nanoscopic factors, by contrast, include rock framework composition and fabric at the microscopic scale, diagenetic alterations in porosity and mineralogy, and pore structure (Olabode and Radonjic, 2014; Vanden Berg et al., 2019; Radonjic et al., 2020; Awejori et al., 2021; Awejori and Radonjic, 2021). All of these factors affect geomechanical, petrophysical, and geochemical properties, all of which are critical for characterizing unconventional "shale" reservoirs. To collect these data, a comprehensive and iterative process that involves a suite of field studies and lab tests is required (Slatt et al., 2012; Evans, 2016; Medina et al., 2020; Benge et al., 2021a, b). Saif et al. (2017) proposed a multidimensional workflow to characterize the Green River Formation, which is a well-known unconventional reservoir. Their results demonstrated that the pore network was dominantly hosted by organic matter and that the pores were largely submicron in size. Despite continuing efforts to characterize these "shale" reservoirs (Bai et al., 2013; Ko et al., 2016; Lohr et al., 2020; Radonjic et al., 2020), it can be challenging to aquire data of appropriate quality and quantity for these reservoirs.

Traditionally, these shale or mudstone reservoirs were typically considered as source rock or seal, primarily because of their high organic content, low porosity, and low permeability. However, in the last decade, technological advances in hydraulic fracturing and horizontal drilling have made it possible to produce directly from these intervals in a commercially feasible manner (Mullen et al., 2010; Yan et al., 2015). As such, these reservoirs are now often considered as source rock and reservoir simultaneously (i.e., self-sourcing). In addition to the high organic content of the self-sourcing aspect, another key component for producing from these reservoirs is the presence of geomechanically rigid intervals that contain a high content of silica cement, carbonate, or both (e.g., Woodford Shale; Fishman et al., 2013). To successfully develop these reservoirs, optimized well orientation and well spacing, appropriate proppant and fluid designs, and reservoir management are further required on the production and engineering side (King, 2010). Therefore, a successful field development includes multidisciplinary integration of geology, petrophysics, geomechanics, geochemistry, and engineering, as well as health, safety, and environment (HSE) practices (fig. 1).

Among the emerging shale/mudrock reservoirs in the United States, the Caney Shale play in the Ardmore basin of southern Oklahoma (fig. 2) is one potential target because of the abundance of organic-rich shale (Andrews, 2007) and the productive, time-equivalent STACK play in north-central Oklahoma. However, the published literature contains few detailed studies that integrate core and log data. Publications on the Caney Shale in Oklahoma mostly focus on outcrops and lack core data (e.g., Cardott, 2017), and the two previous studies we were able to find that use core data, Schad (2004) and Kamann (2006), were from wells in the Arkoma basin, which is separated from the Ardmore basin (this study) by the Arbuckle uplift (fig. 2). In this study, we use one core located in the oil-prone Ardmore basin (fig. 2, well location shown by red star) to focus on rock characterization using an integrated workflow, in which we identify rock types, composition, geomechanical properties, and pore structures. Aiming for a multiscale dataset from the perspectives of geology and engineering, we used core observations and x-ray diffraction (XRD) mineralogy coupled with thin-section petrography, scanning electron microscopy (SEM) / energy dispersive x-ray spectroscopy (EDS), and focused ion beam (FIB)-SEM, as well as rebound hardness and indentation hardness data. The overall goal was to achieve a preliminary understanding of rock types and mineralogy, microporosity, geomechanical properties, and fluid-rock geochemical interactions that can help guide future field development and evaluation. 


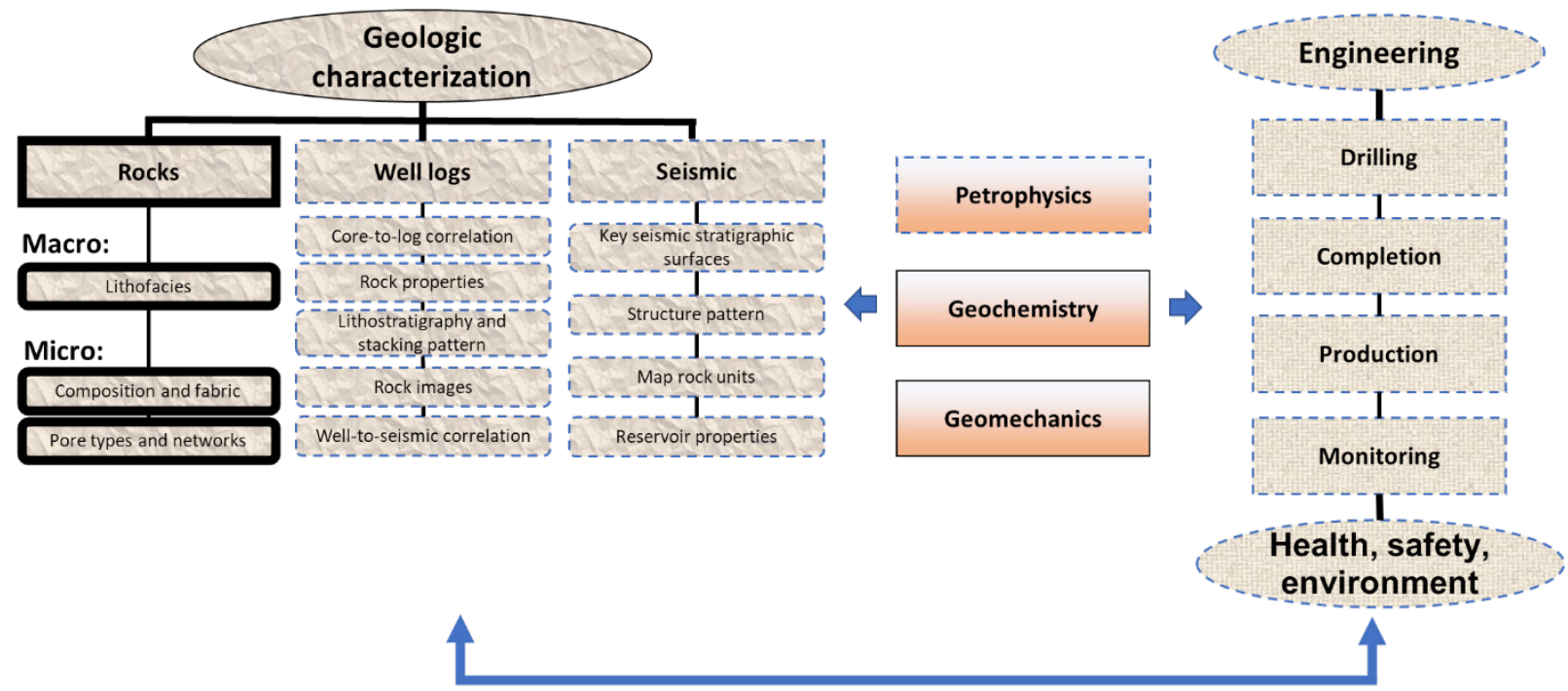

Optimization of operational parameters

Figure 1. Successful shale development includes a multidisciplinary and integrated investigation. It starts with geologic characterization. The next step is petrophysical characterization to better understand the reservoir, followed by geochemistry (related to scaling and clay swelling) and rock geomechanics (related to hydraulic fracturing). Lastly, engineering approaches - including drilling, completion, production, and monitoring - are performed to ensure economic success. Most importantly, environmental protection and personal safety need always be implemented. We focused on the geologic (rock) characterization and then extended our study to geomechanical and geochemical properties. The areas investigated in this study are marked in black boxes, where thick black boxes indicate the areas we have assessed and thin black boxes indicate the areas with partial discussion. The dashed blue boxes indicate tasks that are not included in this study but that will be completed in subsequent studies.

\section{OVERVIEW OF THE MISSISSIPPIAN CANEY SHALE}

The Caney Shale consists of organic-rich and calcareous mudrock and is an emerging unconventional oil and gas resource play in southern Oklahoma within the U.S. southern midcontinent region. The Caney Shale, which is Late Mississippian and mostly Chesteran in age (Andrews, 2007), is found in the Anadarko, Ardmore, Marietta, and western Arkoma basins (Schad, 2004; Kamann, 2006; Houseknecht et al., 2010). The Caney Shale is geographically associated with the south-central Oklahoma oil province (SCOOP) play, where it occurs above the Devonian Woodford Shale. The Caney Shale is partially time equivalent to the Fayetteville Shale in the eastern Arkoma basin and Barnett Shale in the Fort Worth basin, both of which are considered major unconventional shale plays. The Caney Shale is in the oil window in the Ardmore basin, has total organic carbon (TOC) values that range between $0.5 \%$ and $11.0 \%$, thermal maturity index $\left(\mathrm{T}_{\max }\right)$ of $416-530^{\circ} \mathrm{C}$, and Type II and III kerogen (Weber, 1994; Kamann, 2006). The vitrinite reflectance $\left(R_{o}\right)$ varies greatly depending on sample location and ranges between $0.62 \%$ and $2.49 \%$ (Schad, 2004). Porosity measured from core samples can range from less than $1 \%$ to $11 \%$ (Schad, 2004). Porosity (uncorrected for organic content) from

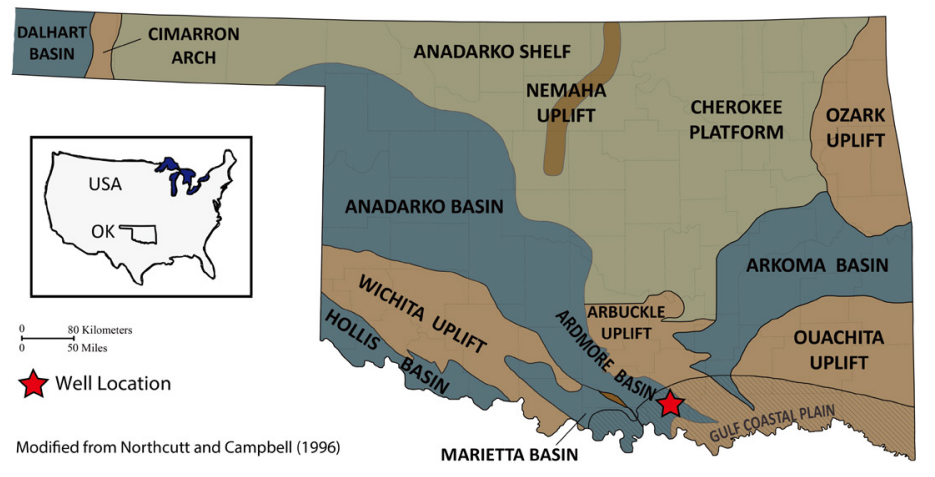

Figure 2. The core featured in this study was obtained from southern Oklahoma within the Ardmore basin, which is bounded by the Arbuckle uplift to the east and the Wichita uplift to the west.

neutron and density logs can reach $10 \%$ to $20 \%$, whereas the density porosity corrected for TOC is less than $4 \%$, and permeability is likely to be in the nanodarcy range (Schad, 2004; Kamann, 2006; Andrews, 2007). Schad (2004) and Kamann (2006) examined the lithology and mineralogy of the subsurface Caney Shale in the western Arkoma basin. They determined that the subsurface Caney mostly consists of multiple types of clay-rich "shale" facies with abundant bulk clay (mostly 20\% to 60\% in XRD mineralogy) and a variable content of silt-sized quartz (mostly 15\% to 30\% in XRD mineralogy). Clay minerals are mostly present as 
illite and mixed-layer illite/smectite. Carbonate occurrence is localized as concretions and discrete layers. Although the completed Caney production profiles for wells in this region are lacking at a rock-type level, wells that target carbonate-rich facies in the Caney show higher production volumes than other wells (Cardott, 2017; Andrews, 2007). Therefore, understanding rock facies and how they affect oil and gas production is necessary for successful Caney Shale play development and predictive modeling of potential production. In addition, production histories from 16 wells targeting the Caney Shale in various locations in nearby counties show that initial production and decline curves are highly variable among these wells (fig. 3; confidential data). Considering the lateral variability in rock types and petrophysical properties as documented in other unconventional reservoirs (e.g., Grammer et al., 2019; Kvale et al., 2020), such variability in production further illustrates the importance of integrating geology and engineering data to optimize the production of these complex reservoirs.

The cored target well (Davy Jones) is located within the Ardmore basin in Marshall County, southern Oklahoma (fig. 2 , red star). The Ardmore basin is a prolific hydrocarbon producing area between the regional Arbuckle uplift to the east and the Wichita uplift to the west (fig. 2). Because gamma ray (GR) and deep resistivity are the only available wireline logs for the cored well (Davy Jones in fig. 4), a nearby well that was logged with a full suite of logs (Jay E. Porter in fig. 4), located 2.75 miles northeast of the Davy Jones well, is used as a reference well to examine the relative position of cored interval in logs and the generalized log characteristics of the Caney Shale (fig. 4). In the reference well (Jay E. Porter), the base of the Caney Shale is defined by an increase in GR to more than 100 API units for approximately 100 feet and a suppression of the neutron and density porosity in the underlying Sycamore Limestone (fig. 4). The Caney in this location, from base to top, decreases overall in resistivity and increases in neutron porosity from approximately 0 to more than $20 \%$. Using the variations observed in the GR log of the Porter well, the Caney Shale can be generally divided into lower, middle, and upper Caney, in which the middle Caney tends to show lower GR (about 100 API) than the lower and upper parts (approaching 150 API) (fig. 4). However, such clearcut GR response is not obviously seen in the cored Davy Jones well, but a distinctively thin middle Caney may be interpreted (fig. 4). Further considering the marked depths and the actual footage of the core, the core of this study may span across the lower to middle Caney, as well as the lower part of the upper Caney (vertical bar at left of the depth scale of the Davy Jones well; fig. 4). In addition, a depth difference greater than 2,000 ft between the cored well and the reference well in a 2.5-mile distance (fig. 4) may indicate fault separation of the Davy Jones and Porter wells.

\section{MATERIALS AND METHODS}

As the initial step of the multidisciplinary integration proposed in fig. 1, this study targeted geologic characterization, with detailed analysis focused on rock types, composition and fabric, and pore systems. After establishing a basic understanding of Caney rock properties, the implications of geochemistry and

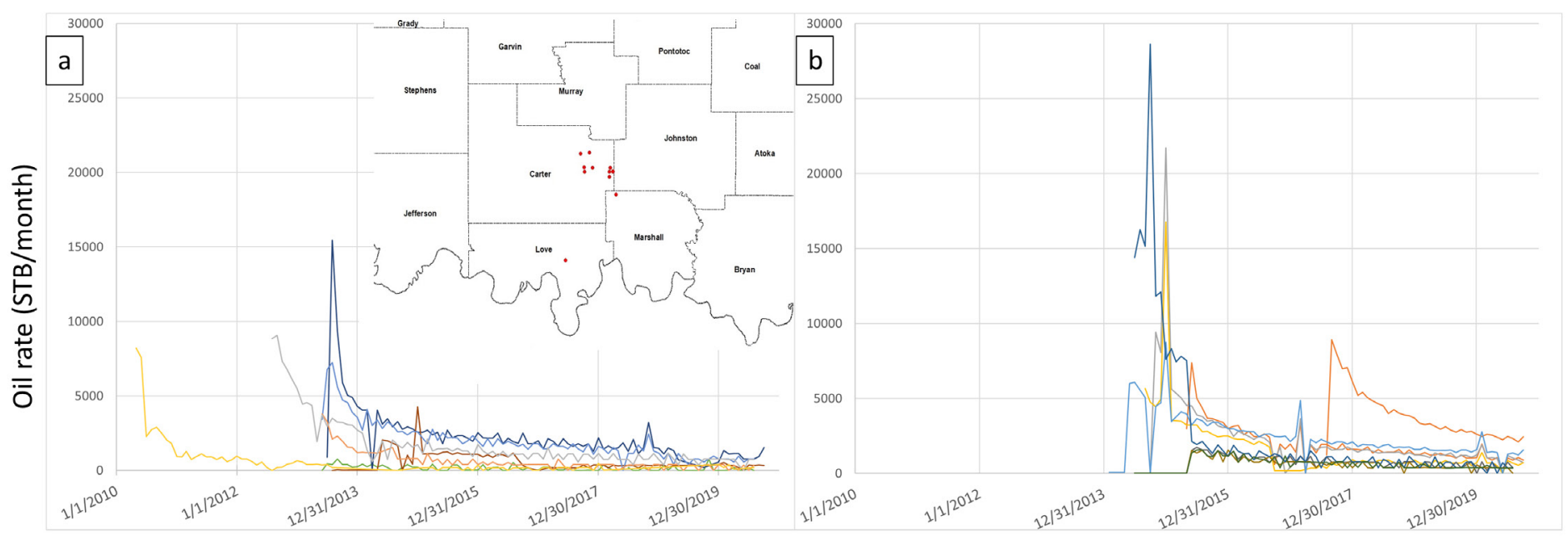

Figure 3. The production histories for wells producing from the Caney formation in the vicinity of the target well: (a) wells that started to produce before 2014 and (b) wells that started to produce after 2014. A few wells started after 2014 showed higher production. 


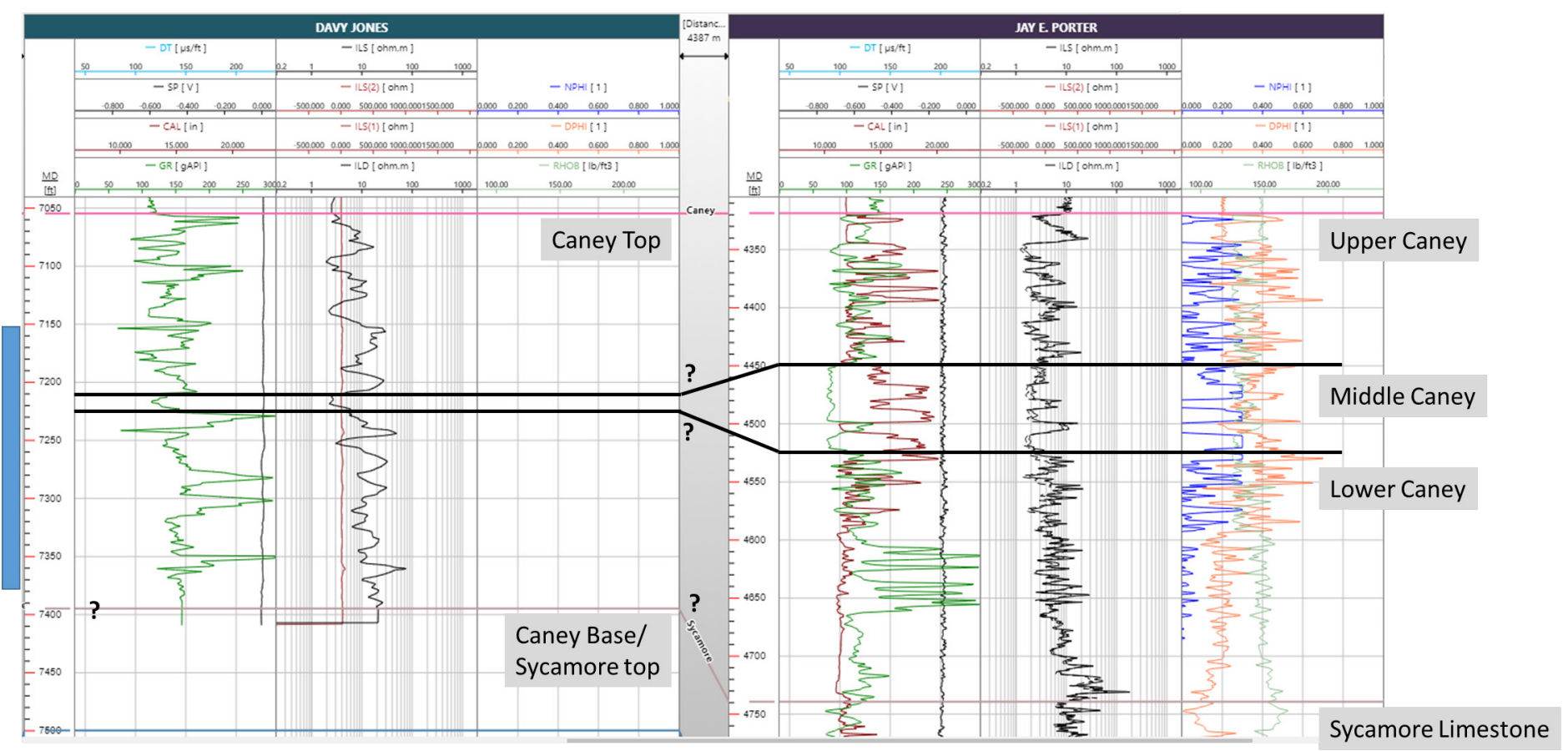

Figure 4. A comparison between the cored well of this study (Davy Jones) and the proposed reference well (Jay E. Porter). In the Davy Jones well, the approximate depth range of the cored interval is marked by the vertical bar at left of depth scale. Due to the different GR responses between these two wells, the subdivision of lower, middle, and upper Caney defined in the reference well is questionable in the cored well, with the correlation lines marked with question marks. Also, because of the abrupt termination in log data, the base of the Caney Shale formation in the Davy Jones well is uncertain, as marked with question mark. See text for details.

geomechanics, as well as their corresponding engineering effects, are discussed. The selected samples were first examined for rock type, composition, structure, and pore type using core and petrographic thin sections, XRD, SEM/ EDS, and FIB-SEM. Rock hardness and elasticity were measured using rebound hardness and indentation testing. Limitations associated with the available core for this study, which is approximately $200 \mathrm{ft}(61 \mathrm{~m})$ in total thickness, result from an overall poor, crumbled, and uncut condition, as well as mislabeled depth marks in many places. As such, it was not possible to conduct a detailed and systematic core description, and samples were selectively acquired to capture representative rock types.

\section{Sample Preparation}

To conduct petrophysical analysis of the representative rock types, nine samples were selected from the Davy Jones core. To prepare thin sections, small billets were cut from these nine samples and then sent to commercial labs to make thin sections. Additional samples were also chosen from the different rock types for XRD and SEM/EDS analyses.

\section{X-ray Diffraction (XRD) Mineralogy}

To establish the mineralogic composition for all rock types, XRD bulk mineralogy analysis was conducted for each type to understand the total mineral content. A total of 16 samples were selected from the core, and 20 grams of powder were prepared from each sample. Samples for XRD analysis were ground to less than 35 microns. The powder XRD analysis was conducted using a Bruker D8 Advance XRD with Lynxeye detector. Each sample was scanned from 5 to 80 degrees 2-theta with a 0.01-degree step and a dwell time of 0.5 seconds. Semi-quantitative XRD analyses were done using the analyzing software DIFFRAC.SUITE EVA provided by Bruker.

\section{Scanning Electron Microscopy (SEM)/Energy Dispersive X-ray Spectroscopy (EDS)}

Samples for SEM/EDS analysis were prepared by cutting them into 4-5 mm thick mini-blocks using SMART CUTT M 1816010 and then drying the blocks at 90 to $105^{\circ} \mathrm{C}$. EDS blocks were cut from the desiccated sample without using water. Samples were polished twice using the Allied High Tech Inc. Multiprep Polisher 8" coupled with the AD-5 Automated Fluid Dispenser to improve image quality for elemental mapping and backscattered electron (BSE) imaging, which are sensitive to topographic effects of the sample surface. The polished shale samples were coated two times using a Cressington carbon coater (graphite rod). 
SEM/EDS maps illustrate a 2-D chemical distribution of main elements, such as $\mathrm{Si}, \mathrm{Al}, \mathrm{Ca}, \mathrm{Mg}$, and $\mathrm{Fe}$. In addition, the SEM analysis can help characterize the pore structures at micron scale, which is essential for unconventional "shale" reservoirs. SEM imaging was carried out using a FEI Quanta 600 field-emission gun environmental scanning electron microscope, in both secondary electron mode and in backscattered electron mode. Images, maps, and spectra were obtained at $20 \mathrm{keV}$ and various magnifications, from a larger field of view to a higher magnification that revealed characteristics of interfaces and surface properties of various phases.

\section{Pore System Architecture}

As discussed in Vanden Berg and Grammer (2016), several studies have shown that standard polishing techniques of fine-grained rocks often produce artificial pores as a result of plucking of grains during polishing. To minimize this problem when evaluating micron- to nanometer-scale pores, SEM photomicrographs were obtained using rock chips $(\mathrm{N}=5)$ that were polished using a JEOL IB-19500CP cross-section polisher argon ion mill. The use of an ion milling machine provides a more pristine polished surface that allows for greater confidence in quantification of the pores and more accurate observations of the spatial distribution of the pores. All samples polished with the ion mill were sputter-coated with gold/palladium or carbon using a Balzers MED 010 sputter coater. Micronto nanometer-scale pores were imaged using a FEI Quanta $600 \mathrm{~F}$ field emission environmental scanning electron microscope (ESEM).

\section{Focused Ion Beam (FIB)-SEM}

To visualize the distribution of organic matter and microporosity in 3-D, one sample was selected for FIB-SEM analysis. A Thermo Scientific ${ }^{\mathrm{TM}}$ Scios $2^{\mathrm{TM}}$ DualBeam $^{\mathrm{TM}}$ was used to serially section and image a portion of the sample. The sample was cut on the edge using a pre-tilted specimen holder, allowing for top-down sectioning of the sample with the FIB and SEM imaging normal to the cut face. Using the automated serial tomography software Auto Slice and View, the sample was cut using a $30 \mathrm{keV} \mathrm{Ga}+$ FIB and imaged normal with a $2 \mathrm{keV}$ SEM beam using the T1 backscattered electron detector. The sample was moved at each slice so that the position of the cut face was optimal for backscattered electron imaging. Slice thickness was set to $10 \mathrm{~nm}$ and the pixel size of the backscattered electron images was 10 $\mathrm{nm}$, yielding a final voxel of $10 \times 10 \times 10 \mathrm{~nm}^{3}$. The pores and the organic matter were segmented out from the stack of SEM images using the Thermo Scientific Avizo for EM software. The different gray levels of the pixels between the pores and organic matter allow the software to identify the features for the segmentation process. These segmented data can then be rendered as individual components of the segment sectioned.

\section{Rebound Hardness Test}

Rebound hardness testing was conducted using the Equotip Piccolo 2 Unit-D hardness tester to evaluate rock mechanical properties. Rebound hardness is tested by dropping a spring-loaded testing tip onto a flat testing surface. As the testing tip rebounds, rebound hardness is calculated using the ratio of rebound and impact velocity as recorded by the device (multiplied by 1,000), with the results being named as the "L-value" (Leeb, 1979). Because rebound hardness records the response of the testing surface to the impact created by the testing tip, it is thought that rebound hardness is a "direct measure for materials hardness" (Kompatscher, 2004, p. 3). To designate a "pseudo-unit" for the testing results, "HLD" is commonly used, with "HL" representing "Leeb Hardness" and " $\mathrm{D}$ " representing the Type D impact body within the Equotip Piccolo 2 Unit-D hardness tester (Leeb, 1979). Due to the largely crumbled nature of the core, four samples with relatively complete sample volume and surface area suitable for rebound hardness testing were selected from the nine samples that were prepared for thin sections. For each sample, five measurements were conducted near the center of the nonfractured, polished testing surface within a close range (around $1 \mathrm{~cm}^{2}$ ). One rebound hardness value is then derived by calculating the arithmetic mean of these five measurements and is denoted as the rebound hardness value of this particular sample.

\section{Indentation}

The Nanovea indenter PB 1000 was used to evaluate three samples in this study. Nanoindentation analysis was conducted using a Vickers diamond nanoindenter with a maximum force of $35 \mathrm{mN}$, a loading and unloading rate of $70 \mathrm{mN} / \mathrm{min}$, and a contact load of $0.08 \mathrm{~N}$. The pause at maximum load was 15 seconds, and the Poisson's ratio used was 0.2 . The indentation sample was cut as an approximately 1-inch cube with polished surfaces. Ten indentation measurements were recorded for each sample during this test, and the average value is reported. 


\section{RESULTS}

Rock Types

Based on thin-section petrography and core observations, three mixed carbonate-siliciclastic rock types were identified: mudstone (fig. 5a), calcareous siltstone (fig. 5b), and silty carbonate (fig. 5c). All three rock types are dominantly massive bedded and share similar types of grain components in various abundance, including silt-sized quartz, skeletal fragments (e.g., agglutinated forams, crinoids), pyrite, and clay minerals (fig. 5). The mudstone is black in color and characterized by a very fine grained and easily crumbled appearance in core due to a mud-dominated rock framework. Mudstones also contain scattered silt-sized quartz grains, agglutinated forams, clusters of organic matter, abundant silt-sized pyrite grains, and an absence of burrows (fig. 5a). The dark gray calcareous siltstone (fig. 5b) contains abundant silt-sized quartz and scattered silt-sized pyrite, skeletal fragments, and clay minerals within a dominantly mud-rich matrix and scattered carbonate cements between grains (fig. 5b). Millimeter-sized burrows are also locally present and are filled with calcite-cemented, silt-sized quartz grains (fig. 5b). The silty carbonate, which is gray in core, is predominantly composed of closely spaced, fine-crystalline dolomite crystals with scattered silt-sized quartz grains, calcite cements, and traces of dead oil (fig. 5c).

\section{Mineralogy}

The Caney samples contain relatively high clay content, with the highest overall clay content observed in

\begin{tabular}{c|c}
$\begin{array}{c}\text { Rock Framework } \\
\text { \&Components }\end{array}$ & $\begin{array}{c}\text { Sedimentary } \\
\text { Structures }\end{array}$ \\
\hline & \\
Mud-dominated &
\end{tabular}

with silt-sized quartz (QZ), organic matter (OM), silt-sized pyrite (PY), clay minerals $(\mathrm{CL})$, agglutinated forams (AF)

Massive-bedded

(a)

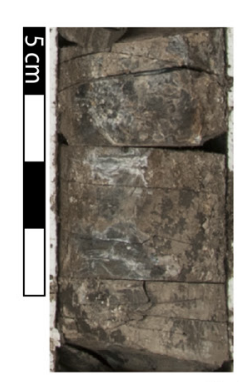

\section{Mudstone}

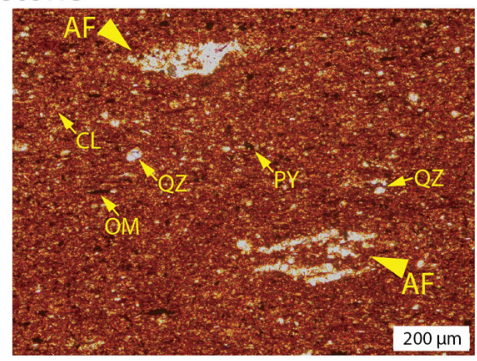

Calcareous Siltstone
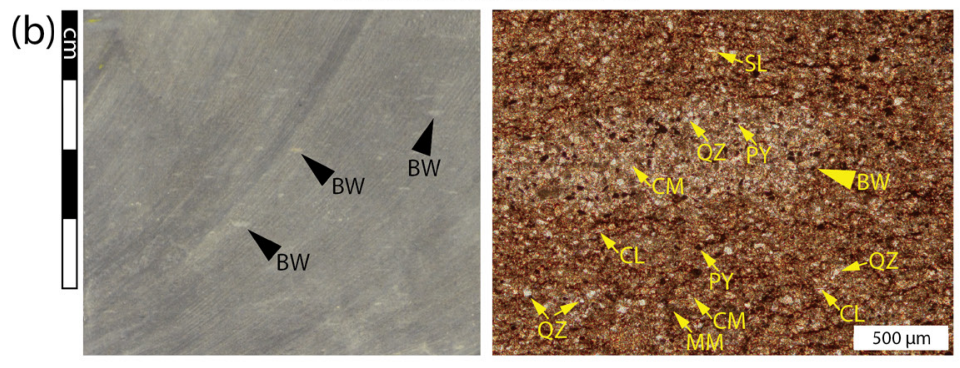

(c)
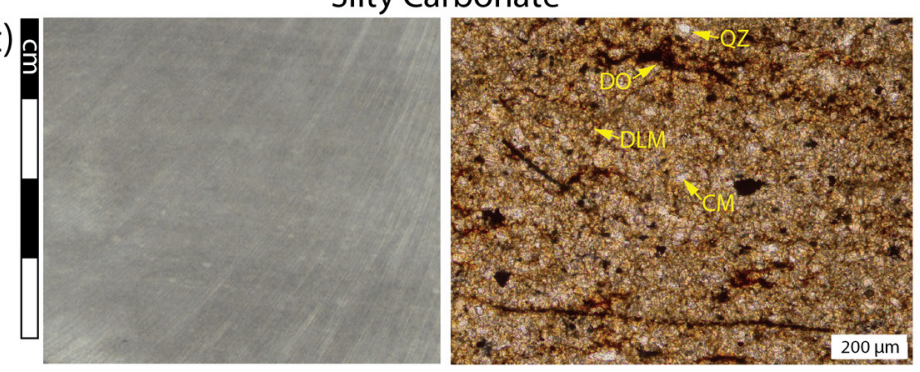

Mixture of mud matrix (MM)

and calcite cement (CM)

with silt-sized quartz (QZ),

shell fragments (SL),

clay minerals $(C L)$,

silt-sized pyrite (PY)

Fine crystalline

with dominantly

dolomite crystals (DLM),

scattered calcite cement (CM),

silt-sized quartz (QZ),

clusters of dead oil (DO)
Mostly massive-bedded, scattered burrows (BW), rarely laminated

Massive-bedded

Figure 5. Core photos (left) and thin-section photomicrographs (right) of (a) mudstone, (b) calcareous siltstone, and (c) silty carbonate. For each rock type, core photo (left) and thin-section photomicrograph (right) are from the same sample. In thin-section photomicrographs, the horizontal scale is 200 and 500 microns or $\mu \mathrm{m}$. Mudstone (a) is dominated by a muddy matrix. Calcareous siltstone (b) contains abundant silt-sized quartz with scattered calcite cement. Silty carbonate (c) is characterized by a crystalline framework, which contains abundant dolomite grains. All thin-section photos were taken under plane-polarized light. AF - agglutinated forams, CL - clay minerals, QZ - quartz, OM - organic matter, PY - pyrite, BW - burrows, SL - shell fragments, CM - calcite cement, MM - mud matrix, DO - dead oil, DLM - dolomite. In core photos, the scale bars are different among examples. 
the mudstone samples ( $27 \%$ to $55 \%, \mathrm{~N}=12$ ) (fig. 6, table 1). In contrast, silty carbonate contains $14 \%-15 \%$ bulk clay while calcareous siltstone contains a bulk clay content

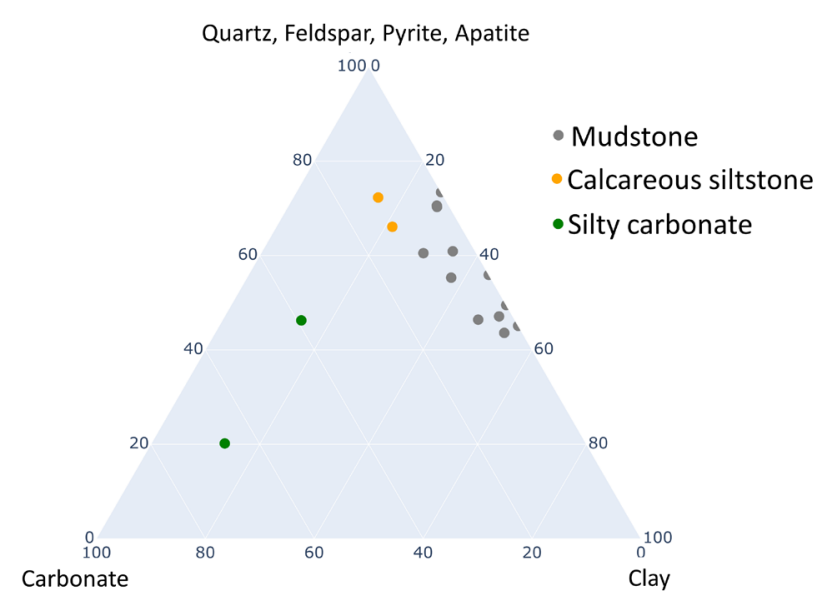

Figure 6. Target well mineralogy associated with three identified rock types. of approximately $16 \%$ to $21 \%$ (table 1 ). The predominant clay types are illite and mixed layer illite/smectite, with authigenic illite also being present between carbonate grains (fig. 7, table 1). Quartz is abundant in all three rock types, ranging from $28 \%$ to $63 \%$ in the mudstone, $55 \%$ to $66 \%$ in the calcareous siltstone, and $13 \%$ to $36 \%$ in the silty carbonate (fig. 6, table 1). Carbonate minerals are most abundant in silty carbonate (39\% to $66 \%$, dominated by dolomite), followed by calcareous siltstone (around $12 \%$, calcite and dolomite) and mudstone (2\% to nearly $10 \%$, calcite and dolomite) (fig. 6, table 1 ). The heterogeneity in mineralogy is also present at the SEM scale. Despite the predominant massive-bedded structure with no discernable bedding (fig. 7), certain samples show distinctive heterogeneity in terms of variations in mineralogy at a micron scale, such as layering related to the distribution of clay minerals (fig. 8).

SEM/EDS maps (figs. 9-11) show spatial 2-D distribution of the mineralogical makeup of each sample and are consistent with bulk analyses obtained from XRD
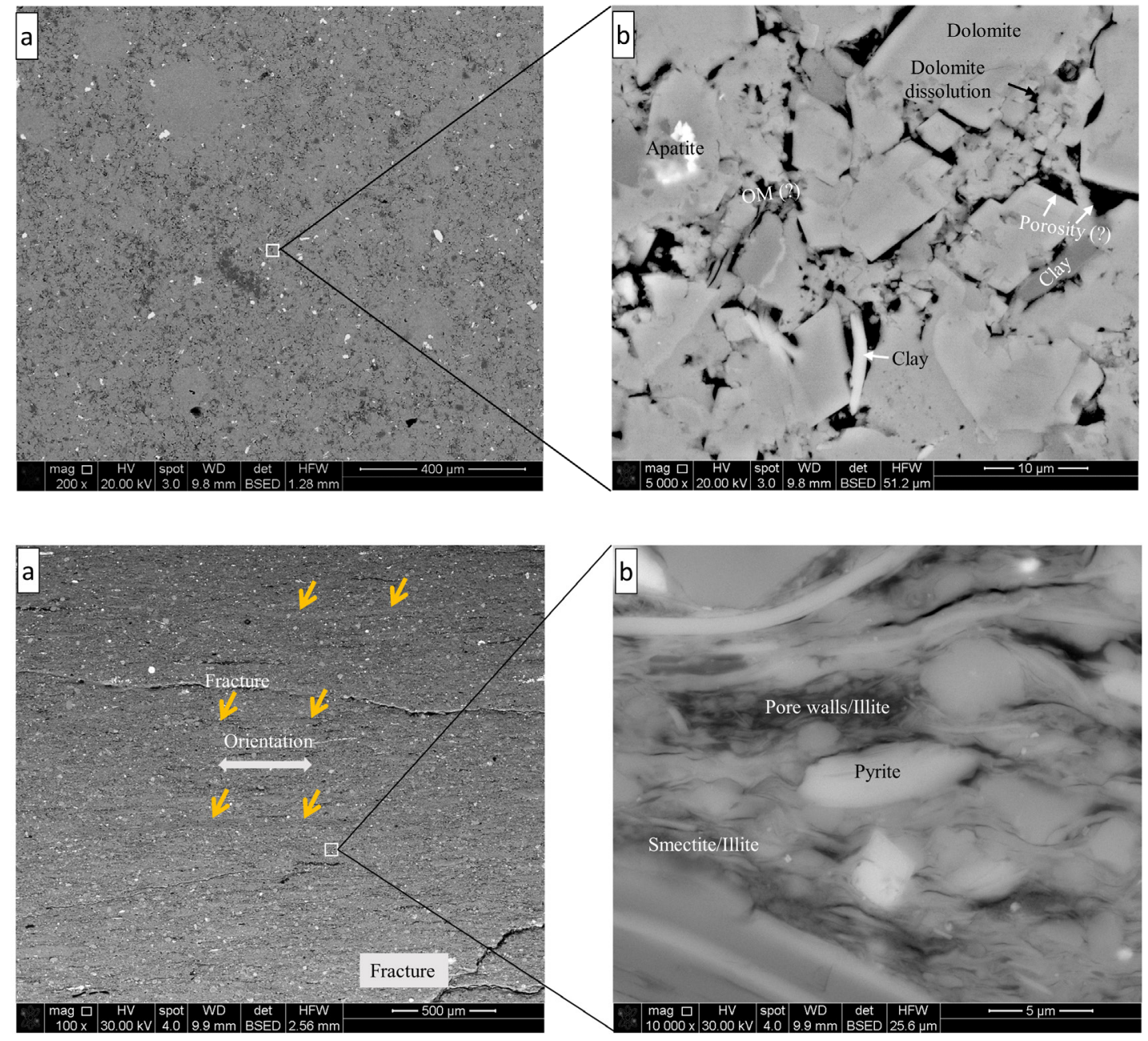

Figure 7. Mudstone at $7,152 \mathrm{ft}$, polished surface, in backscattered electrons (BSE) mode: (a) large field view and (b) higher magnification. Interparticle porosity is visible between carbonate and other grains as well as organic matter and clays. Because it can be difficult to distinguish organic matter (OM) from porosity, both are labeled with question marks. Apatite is seen in the high magnification image.

Figure 8. Mudstone at $7,305 \mathrm{ft}$, polished surface, in backscattered electrons (BSE) mode: (a) large field view with parallel bedding planes, yellow arrows represent thin layers that are likely created by fine-scale variation in mineralogy; (b) higher magnification showing smectite-illite, pore-lining illite, and pyrite. 
Table 1. XRD mineralogy of the 16 Caney samples acquired in this study marked by rock types.

\begin{tabular}{|c|c|c|c|c|c|c|c|c|c|c|c|c|c|c|c|c|}
\hline $\begin{array}{l}\text { Depth } \\
\text { (ft) }\end{array}$ & $\begin{array}{c}\text { Quartz } \\
\text { (\%) }\end{array}$ & $\begin{array}{l}\text { Albite } \\
(\%)\end{array}$ & $\begin{array}{c}\text { Pyrite } \\
\text { (\%) }\end{array}$ & $\begin{array}{c}\text { Apatite } \\
(\%)\end{array}$ & $\begin{array}{c}\text { Glauconite } \\
(\%)\end{array}$ & $\begin{array}{c}\text { Ankerite } \\
(\%)\end{array}$ & $\begin{array}{c}\text { Calcite } \\
(\%)\end{array}$ & $\begin{array}{c}\text { Dolomite } \\
\text { (\%) }\end{array}$ & $\begin{array}{l}\text { Illite } \\
(\%)\end{array}$ & $\begin{array}{c}\text { Illite- } \\
\text { smectite- } \\
\text { muscovite } \\
(\%)\end{array}$ & $\begin{array}{c}\text { Kaolinite } \\
(\%)\end{array}$ & $\begin{array}{c}\text { Chlorite } \\
\text { (\%) }\end{array}$ & $\begin{array}{c}\text { Quartz, } \\
\text { feldspar, } \\
\text { pyrite, } \\
\text { apatite } \\
(\%)\end{array}$ & $\begin{array}{c}\text { Carbonate } \\
(\%)\end{array}$ & $\begin{array}{l}\text { Clay } \\
(\%)\end{array}$ & $\begin{array}{l}\text { Rock } \\
\text { types }\end{array}$ \\
\hline 7,152 & 57.3 & / & / & 3.6 & / & / & 4.1 & / & 22.8 & 9.2 & 3 & / & 60.9 & 4.1 & 35 & Mudstone \\
\hline 7,176 & 41.1 & / & 3.3 & I & 1.9 & / & 1.7 & 5 & 28.2 & 11.7 & 7.1 & / & 46.5 & 6.7 & 47 & Mudstone \\
\hline 7,200 & 38.6 & I & 4.8 & I & 3.7 & / & 2.5 & / & 30.8 & 17.5 & 2.1 & / & 47.1 & 2.5 & 50.4 & Mudstone \\
\hline 7,219 & 34.5 & 9.1 & I & I & / & / & 3.3 & / & 32.9 & 16.7 & 3.5 & I & 43.6 & 3.3 & 53.1 & Mudstone \\
\hline 7,274 & 45.5 & 4 & I & I & I & I & / & I & 30.2 & 14.9 & 2.8 & 2.6 & 49.5 & N/A & 50.5 & Mudstone \\
\hline 7,281 & 47.5 & 3.6 & I & 4.2 & I & 4.4 & I & 2.8 & 23.3 & 11.7 & 2.5 & / & 55.3 & 7.2 & 37.5 & Mudstone \\
\hline 7,305 & 28.1 & / & 6.7 & 25.7 & / & I & / & 9.7 & 14.9 & 14.9 & / & I & 60.5 & 9.7 & 29.8 & Mudstone \\
\hline 7,350 & 44.2 & 4 & 4.1 & 3.6 & I & I & I & / & 31.1 & 9.5 & 3.5 & / & 55.9 & $\mathrm{~N} / \mathrm{A}$ & 44.1 & Mudstone \\
\hline 7,357 & 12.9 & 7.3 & / & I & I & I & / & 66.3 & 3.2 & 10.3 & / & / & 20.2 & 66.4 & 13.5 & $\begin{array}{c}\text { Silty } \\
\text { carbonate }\end{array}$ \\
\hline 7,362 & 63.6 & 6.4 & 3.4 & I & / & I & I & I & 12.5 & 14.1 & I & / & 73.2 & N/A & 26.5 & Mudstone \\
\hline 7,389 & 31.9 & 9.3 & 3.9 & I & I & / & / & I & 40.6 & 14.3 & I & I & 45.1 & N/A & 54.9 & Mudstone \\
\hline 7,406 & 35.6 & 10.6 & I & I & / & I & 5.9 & 33.4 & 6.7 & 7.8 & / & / & 46.2 & 39.2 & 14.5 & $\begin{array}{c}\text { Silty } \\
\text { carbonate }\end{array}$ \\
\hline 7,413 & 66.3 & 3.2 & 2.8 & I & I & 4 & 2.6 & 5.5 & 11.5 & 4.1 & I & I & 72.3 & 12.1 & 15.6 & $\begin{array}{l}\text { Calcareous } \\
\text { siltstone }\end{array}$ \\
\hline 7,419 & 55.4 & 7.4 & 3.3 & I & / & 3.3 & 4.1 & 5.2 & 7.3 & 14 & I & I & 66.1 & 12.6 & 21.3 & $\begin{array}{l}\text { Calcareous } \\
\text { siltstone }\end{array}$ \\
\hline 7,422 & 55.5 & 12.5 & 2.3 & I & / & I & / & 2.3 & 17 & 10.4 & I & / & 70.3 & 2.3 & 27.4 & Mudstone \\
\hline 7,429 & 60.1 & 1.5 & 2.7 & I & 6.3 & I & I & 2.2 & 18.1 & 9.1 & I & I & 70.5 & 2.2 & 27.2 & Mudstone \\
\hline
\end{tabular}



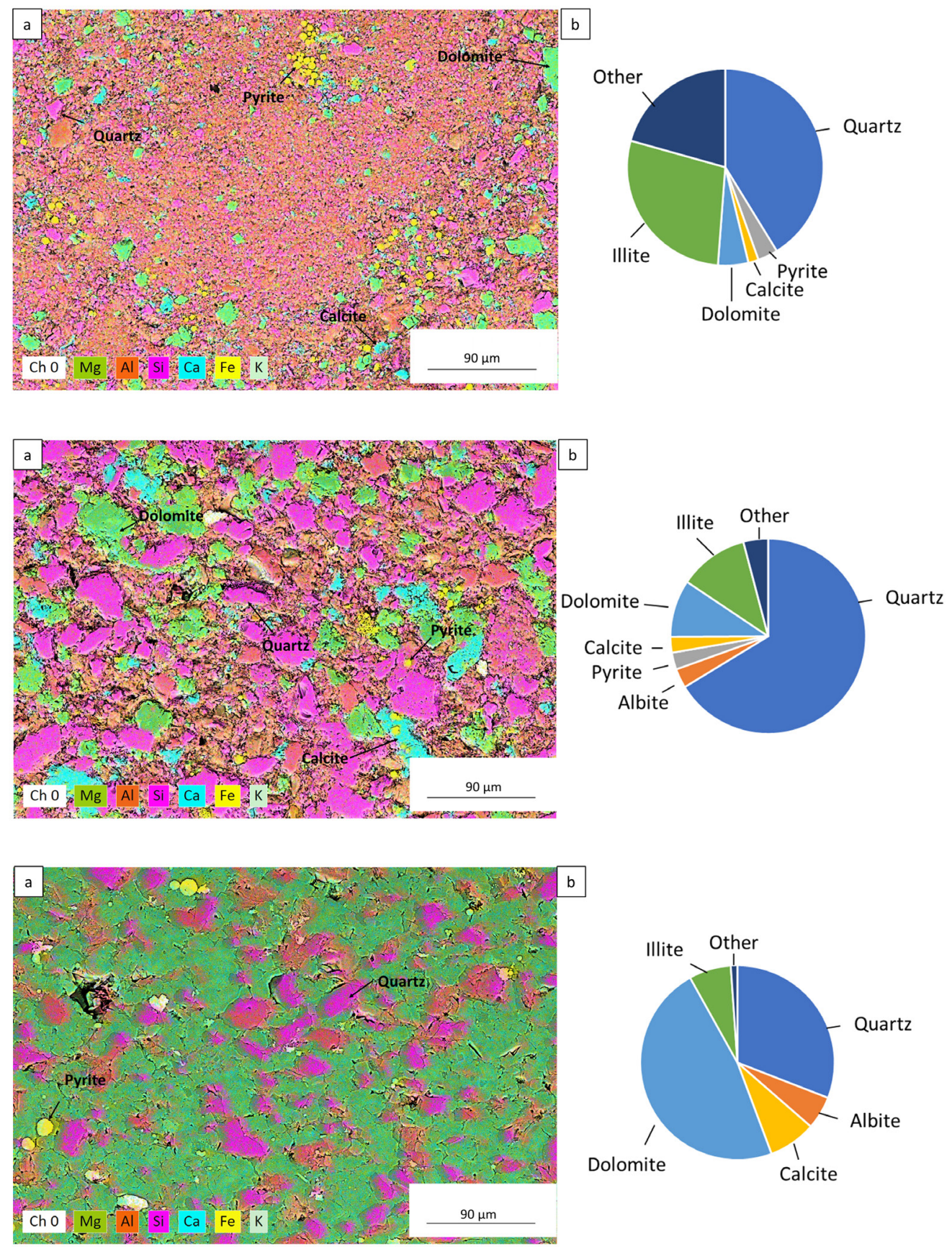

Figure 11. Mineralogy for silty carbonate at 7,357 ft. (a) SEM/EDS map showing abundant dolomite with embedded quartz grains. (b) Bulk mineralogy from XRD showing dominant dolomite and quartz. Clay minerals are least abundant in silty carbonate compared with the two other rock types.
Figure 9. Mineralogy for mudstone at $7,176 \mathrm{ft}$. (a) SEM/EDS map minerals with embedded quartz, dolomite, and calcite grains. (b) Bulk mineralogy from XRD. The mineral content is similar to that indicated in the SEM/EDS map.

Figure 10. Mineralogy for calcareous siltstone at 7,413 ft. (a) SEM/EDS map showing majority of grains are quartz, dolomite, and calcite. (b) Bulk mineralogy from XRD showing the major minerals include quartz, dolomite, and calcite with lesser amounts of clay minerals, such as illite. and calcite as well as sparsely distributed pyrite. Matrix is finer clay analysis (table 1), supporting rock type identification. Mudstones typically show greater than $50 \%$ clay-sized grains (less than 3.9 microns in size) with the highest clay content and the lowest carbonate content (less than 10\%) among the three rock types, as represented by abundant aluminum and scarce calcium and magnesium (fig. 9). Calcareous siltstones typically contain abundant (greater than $50 \%$ ) silt-sized quartz grains (3.9 to 62.5 microns in size; represented by abundant silica in fig. 10) with an intermediate amount of carbonate (represented by calcium and magnesium in fig. 10) and clay content (represented by aluminum in fig. 10). Silty carbonate typically contains the highest carbonate content (dolomite, represented by abundant magnesium in fig. 11) with varying amounts of silt-sized quartz (represented by common silica in fig. 11) and the least clay content among the three rock types. It should be noted that mineralogy data of certain mudstone and siltstone samples show overlaps (e.g., 7,305 ft vs. 7,413 $\mathrm{ft}$, table 1), suggesting the presence of rock types with "transitional" mineralogy between mudstone and siltstone that can be challenging to define without thin sections (e.g., muddy siltstone vs. silty mudstone). 
In addition, mudstone shows more heterogeneity in grain size at the micron to millimeter scale. As shown in fig. 9 (mudstone), relatively smaller grains are observed in the upper part, while larger grains are observed in the bottom left corner. In contrast, calcareous siltstone and silty carbonate show less heterogeneity at the same scale. Figure 10 (calcareous siltstone) shows more homogeneous distribution of the relatively larger quartz and dolomite grains among clays, and fig. 11 (silty carbonate) shows relatively evenly distributed quartz grains encased within a crystalline framework of dolomite.

\section{Natural Fractures and Pore Types}

In shale formations, natural fractures may not only provide storage space for petroleum fluids but also serve as conduits for petroleum fluids to access wellbores. Natural fractures play a major role in Caney Shale production (Andrews, 2007), and the existence of natural fractures that are partially to completely mineralized with calcite and other minerals is confirmed in this core. Figure 12 shows a typical filled fracture in the Caney Shale from the Davy Jones core. As observed, the fracture aperture is approximately 120 microns filled with carbonate minerals and based on BSE appears to contain pyrite inclusions, suggesting that the fill is not a result of sample preparation or other means of contamination. In this study, fractures that are partially to fully mineralized are interpreted to be natural in origin, which is consistent with the observations in the "Mississippian Limestone" / STACK play in north-central Oklahoma (Wang et al., 2019). In contrast, artificially induced fractures, which can be produced during the recovery, transportation, and storage of core samples, often exhibit fresh fracture walls without mineral lining (cements) or evidence of relative movement. However, it is recognized that distinguishing natural fractures from induced fractures solely based upon the presence of cements can be problematic (e.g., Gale et al., 2014).

Pores in the Caney Shale samples are typically nanometer to micrometer in scale and generally only observable with SEM analysis. Pore types were identified and described using the classification scheme for pores in mudrocks proposed by Loucks et al. (2012). Common pore types in the Caney Shale include interparticle (InterP) pores, intraparticle (IntraP) pores, and organic matter (OM) pores (figs. 13-15). Interparticle pores occur along the boundaries of mineral grains, skeletal fragments, and other particles. Some of the elongated interparticle pores are suspected to be shrinkage cracks similar to the sample preparation artifacts described by Loucks et al. (2012). Intraparticle pores occur within individual particles, such as pyrite framboids (as intercrystalline pores) and clay particles (between cleavage sheets; figs. 13-15). Organic matter pores exhibit a spongy morphology within dark organic matter (figs. 13, 15). Under FIB-SEM, both organic matter and micronto nanometer-scale porosity exhibit a highly connected network in 3-D at the micron to nanometer scale, while the networks of organic matter and microporosity show some degrees of correlation (fig. 16). 

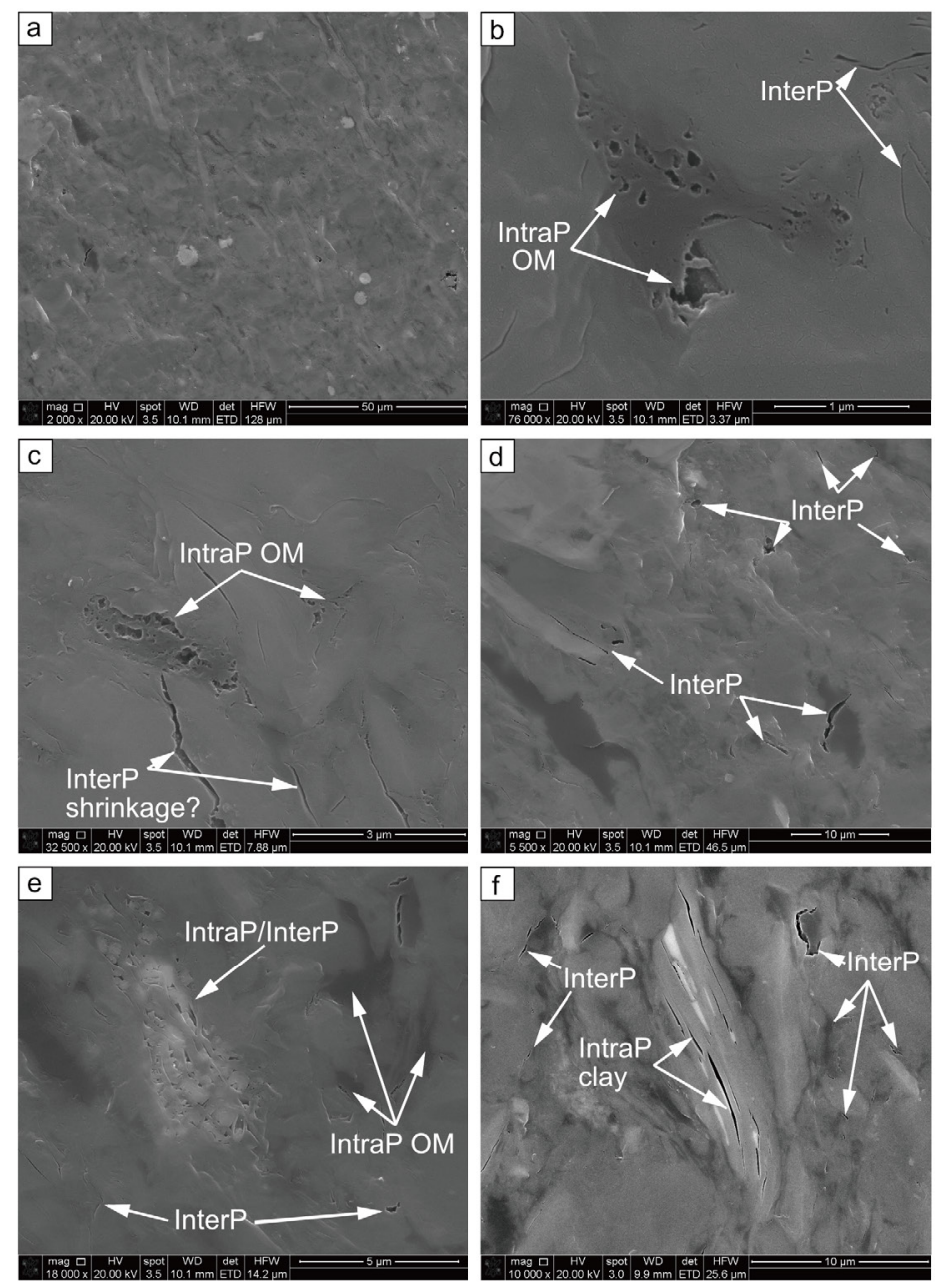

Figure 13. SEM photomicrographs of mudstone samples: (a) overview of rock texture, (b) intraparticle (IntraP) organic matter (OM) pores, (c) intraparticle organic matter pores and possible shrinkage cracks, (d) nonporous organic matter, interparticle (InterP) pores, and possible shrinkage cracks, (e) interparticle and intraparticle pores in pyrite framboids in clay (?) particle and organic matter pores, and (f) interparticle pores and intraparticle clay pores.

\section{Rock Mechanics}

Because of the poor preservation quality and crumbled nature of the mudstone samples in the core (e.g., fig. 5a, left photo), two calcareous siltstone samples and two silty carbonate samples were selected for testing rebound hardness. For calcareous siltstone, rebound hardness values are close to 600 HLD, whereas the values of silty carbonate range from 720 to 730 HLD (table 2). Such distinctly higher rebound hardness values in the silty carbonate can be related to a crystalline rock framework that is supported by pervasive dolomite and calcite cement (fig. 5c). In addition, as indentation is effective for smaller-sized samples, we tested elastic modulus with nanoindentation on the three rock
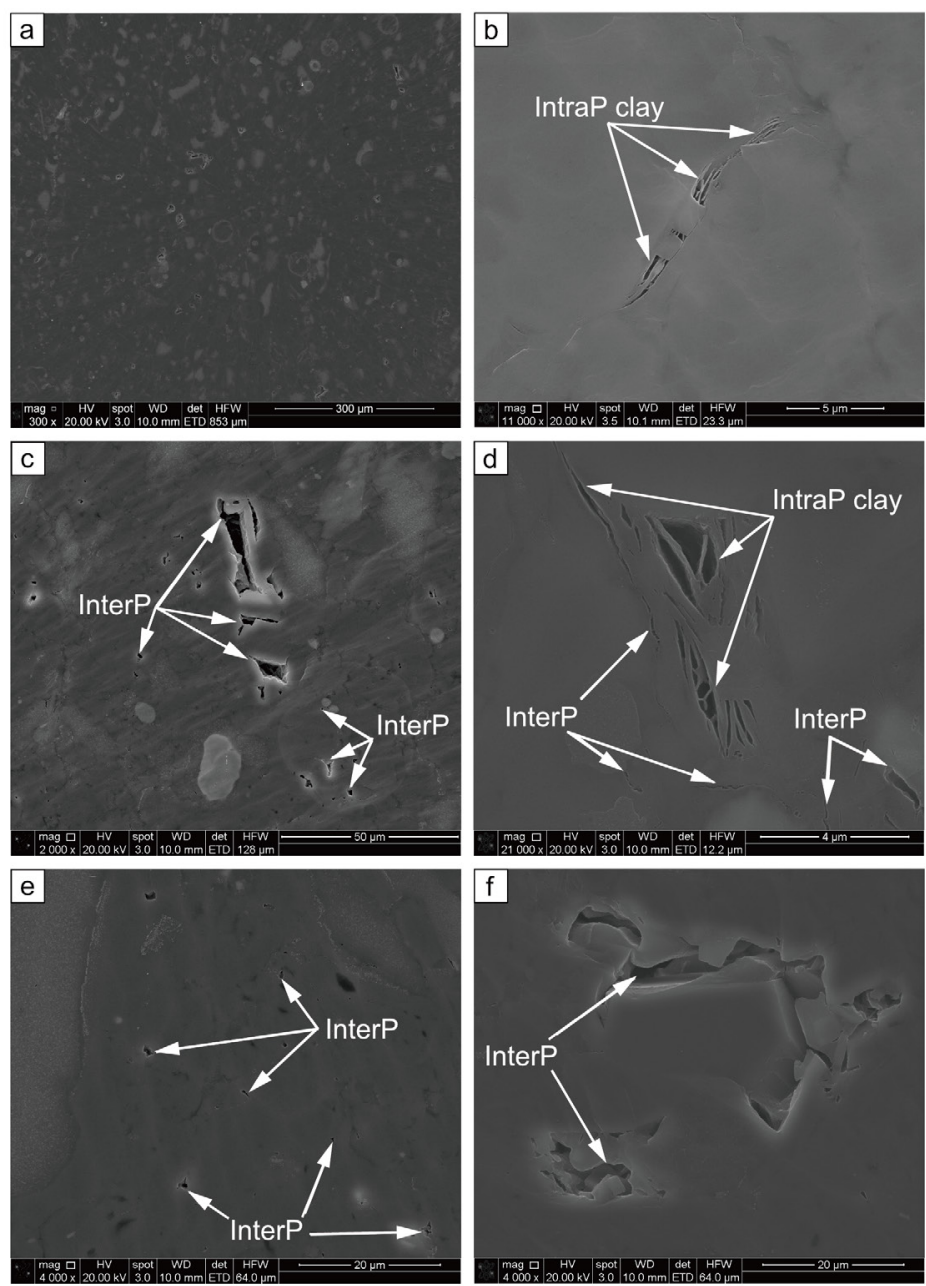

Figure 14. SEM photomicrographs of silty carbonate samples: (a) overview of rock texture, (b) intraparticle (IntraP) pores in clay particle, (c) interparticle (InterP) pores, (d) interparticle and intraparticle pores associated with clay particles, (e) scattered interparticle pores, and (f) interparticle pores. Scales vary from image to image.

types investigated for this study. Nanoindentation measurements were collected on the same sample surfaces that were used to obtain chemical elemental maps (figs. 9-11). We conducted 10 indentation measurements and reported the average on each sample. Mudstone, calcareous siltstone, and silty carbonate show an average Young's modulus (GPa) of 20.7, 44.9, and 80.3, respectively (table 3 ).

\section{DISCUSSION}

The integrated macro- and microscale characterization provides an opportunity to understand rock properties of the Caney Shale. The three identified rock types have unique rock fabrics, pore types, and mineralogy. 

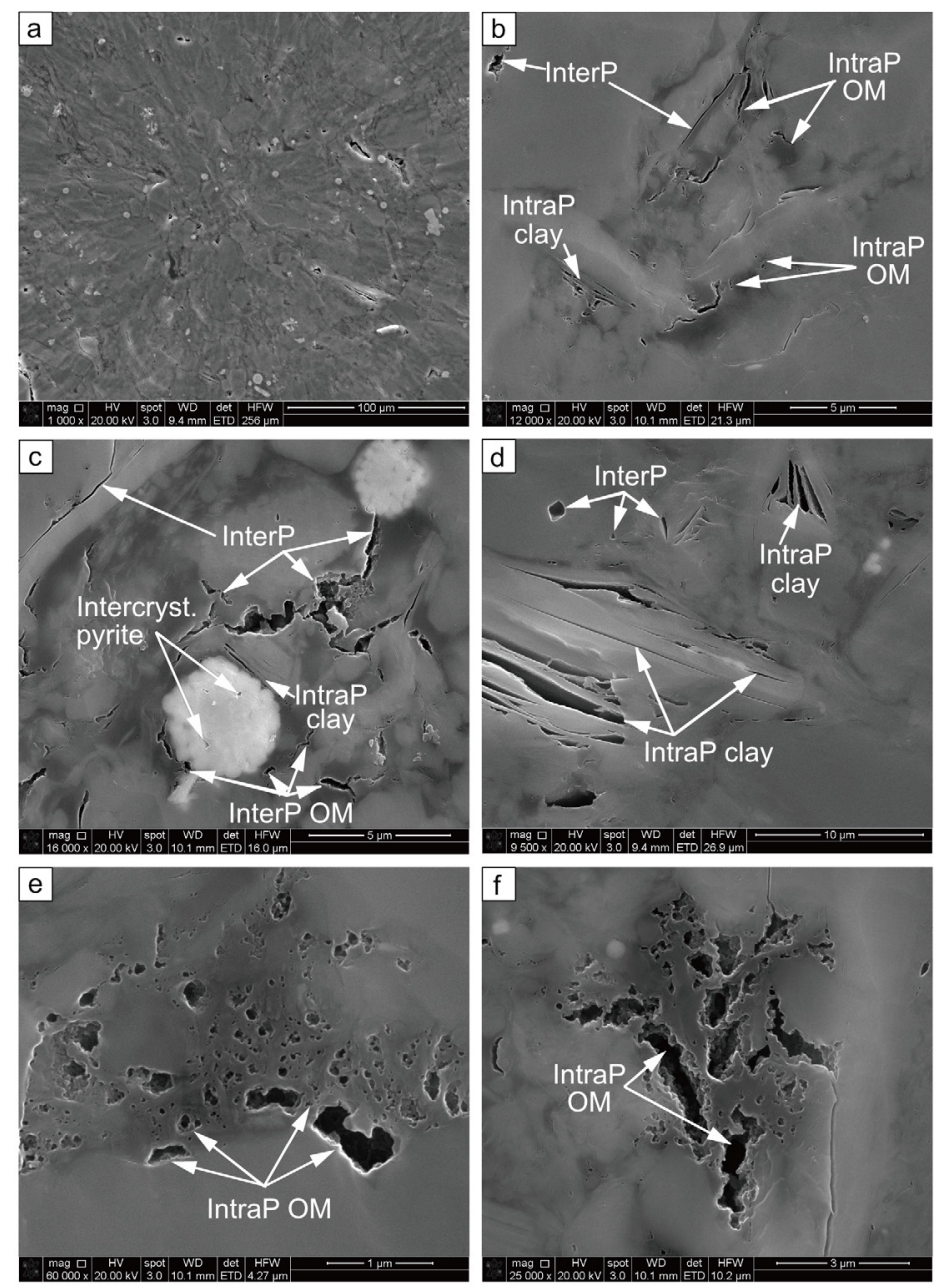

Figure 15. SEM photomicrographs of calcareous siltstone samples: (a) overview of rock fabric, (b) interparticle (InterP) pores between organic matter (OM) and grains, and intraparticle (IntraP) pores associated with clay particles, (c) interparticle pores, interparticle organic matter with pores, and intercrystalline pores within a pyrite framboid, (d) interparticle pores and intraparticle pores in clay grains, and (e and f) organic matter pores.

Recognizing these differences is essential to identifying reservoir units as well as understanding rock elasticity and the potential for scale formation during completion and production of Caney wells.

\section{Origin and Reservoir Quality of Facies}

Based on observations in core and thin section, the three identified Caney facies types likely represent different energy conditions during deposition. Considering its mud-dominated rock framework and lack of burrows (fig. 5a), the mudstone facies likely reflects a low energy, restricted environment that lacked dissolved oxygen, in which suspension settling was the dominant sedimentary process. In contrast, the calcareous siltstone (fig. 5b), which contains higher calcite content and carbonate allochems
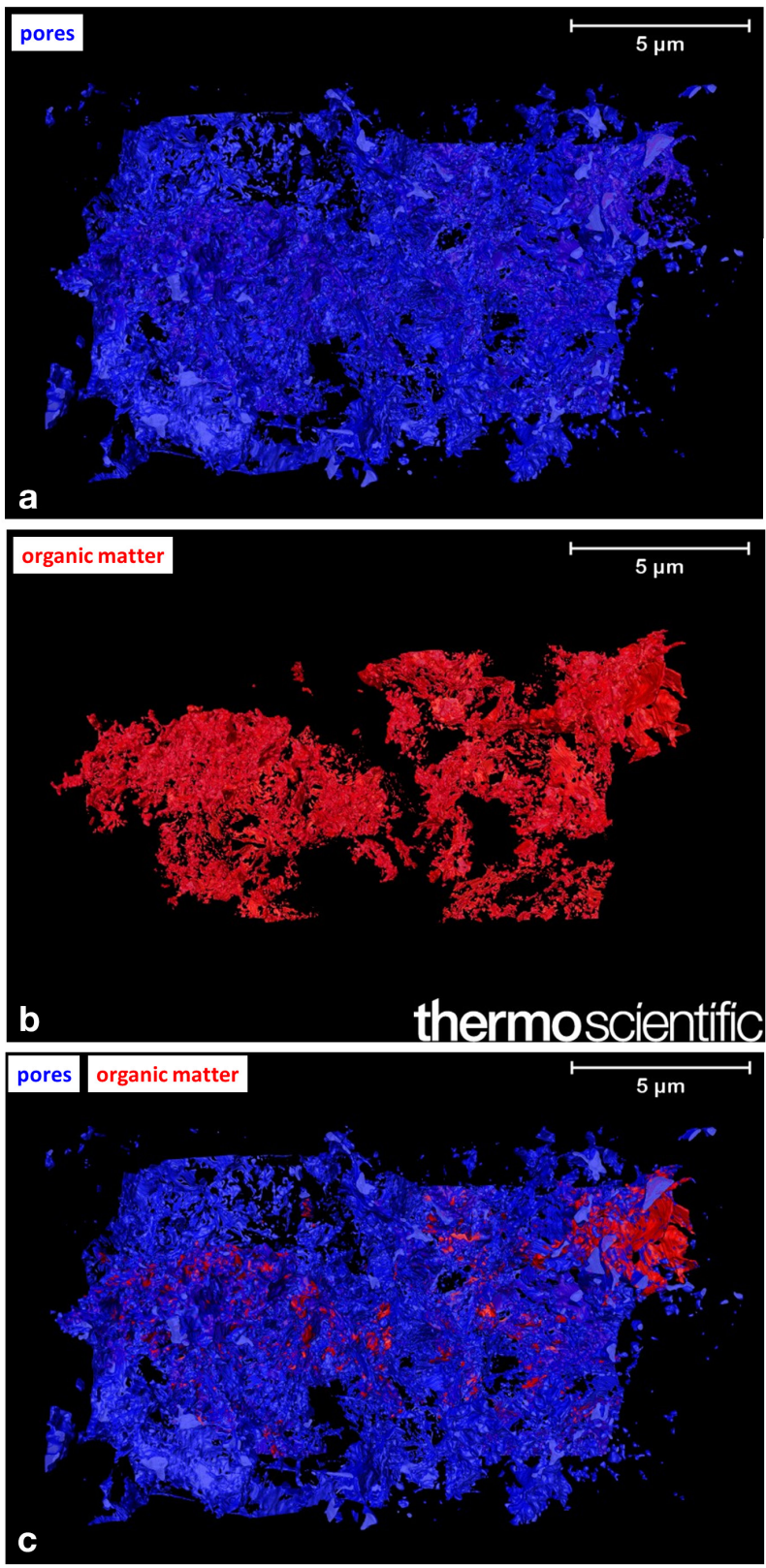

Figure 16. Segmentation of (a) pores, (b) organic matter, and (c) combination of pores and organic matter under FIB-SEM.

along with the presence of burrows, indicates somewhat higher energy, more oxygenated bottom water than the mudstone. Sedimentary structures that imply higher energy deposition, such as cross lamination, are present but rare, suggesting an overall low energy depositional environment with intermittent higher energy influx, possibly due to storms. The silty carbonate (fig. 5c) is mostly composed of closely spaced dolomite crystals and may have replaced an original grain-dominated limestone facies, such as a packstone-grainstone, which would indicate higher energy original deposition compared to the two other facies and may be related to shallower water 
Table 2. Rebound hardness values for four samples selected from calcareous siltstone and silty carbonate, with two samples for each rock type. Values of the two calcareous siltstone samples are close to 600 HLD, whereas the silty limestone samples range from 720 to 730 HLD. Each rebound hardness value represents the arithmetic mean from five measurements.

\begin{tabular}{lcc}
\hline \hline Rock types & $\begin{array}{c}\text { Rebound hardness (HLD; 2 } \\
\text { samples for each rock type) }\end{array}$ \\
\hline Calcareous siltstone & 595 & 604 \\
Silty carbonate & 722 & 730 \\
\hline
\end{tabular}

or storm deposits or possibly downslope transport of sediment. Downslope mass transport deposits (turbidites and debris flows) have been identified in other Caney Shale sections (Wang et al., 2021).

In terms of reservoir properties, micron- to nanometerscale porosity is likely the primary contributor to reservoir quality as none of these facies show visible pores macroscopically on the core surface or at the petrographic scale (fig. 5). Although tight rock analysis data are not available in this study, reservoir quality of the three Caney facies may be inferred based on the data in the partially time-equivalent STACK play farther north, which contains similar facies types as compared to this study (Wang et al., 2019). Based on data from three STACK cores, mudstones show the highest average porosity, whereas silty carbonate (skeletal packstone-grainstones) show the lowest average porosity (Wang et al., 2019). Mudstones in the STACK play contain the highest average bulk clay and TOC content, similar to the Caney mudstones in this study. The clay and organic material can host abundant microporosity related to clay minerals and organic matter (Loucks et al., 2012), resulting in high porosity values. The potential association of microporosity with organic matter in the Caney samples is also suggested by the micron- to nanometer-scale porosity distribution pattern observed in FIB-SEM (fig. 16). In the silty carbonate facies of the STACK play, pervasive carbonate cement occludes interparticle pore spaces and, combined with the lowest average bulk clay content, has the lowest average porosity. The calcareous siltstone facies has intermediate average porosity values. Because of the similarity to the STACK facies in depositional fabric and texture, as well as percentage of clay, quartz silt, and carbonate, it is likely that such a relationship between porosity and facies types is also present in the Caney samples in this study. In that case, the mudstones would be the primary potential reservoir and the silty carbonate the sealing facies.
Table 3. Young's modulus of three rock types measured from indentation (reported the average of 10 measurements for each sample).

\begin{tabular}{lc}
\hline Rock type & Young's modulus (GPa) \\
\hline Mudstone & 20.7 \\
Calcareous siltstone & 44.9 \\
Silty carbonate & 80.3 \\
\hline
\end{tabular}

Impact of Facies Distribution on Reservoir Heterogeneity

Although derived from limited samples, the three rock types identified in this study (fig. 5) are likely representative of a part of the Caney Shale throughout southern Oklahoma as they are very similar to the facies documented in the Arkoma basin in southern Oklahoma (Kamann, 2006; east of the area of this study; fig. 2). At a broader scale, similar mixed carbonate-siliciclastic facies assemblages have been reported in several unconventional reservoirs around the world, such as the Middle Bakken Member in the Williston basin (Sarg, 2012), the Vaca Muerta Formation of the Neuquén basin in Argentina (Eberli et al., 2017), and the STACK play of the Anadarko basin (Wang et al., 2019). This indicates that similar types of unconventional reservoirs could serve as depositional analogs for the Caney Shale and provide insight into the regional depositional system.

Considering the potentially different reservoir quality of the three Caney facies identified in this study, the distribution of facies vertically in core, and the likely horizontal distribution of facies based on analogs, reservoir compartmentalization at multiple scales would be expected. From a vertical standpoint, the heterogeneous distribution of the three facies types creates heterogeneities in mineralogy, total organic carbon, petrophysical properties (reservoir/seal), and geomechanical properties (potential for hydraulic fracturing), all of which contribute to vertical heterogeneity in reservoir quality across multiple scales and, potentially, create vertically stacked zones for production. Due to the overall poor, crumbled, and uncut condition of the core of this study (e.g., fig. $5 a)$, mislabeled depth marks in many places in the core, and the lack of petrophysical core and log data of this study, it is challenging to conduct a detailed, systematic characterization of facies and reservoir distribution in core and further tie it with a full suite of log data. As discussed above, $\log$ pattern analogs and the reservoir potential of 
facies in other mixed carbonate-siliciclastic unconventional reservoirs that are similar to the identified facies types observed in the Caney from this study can provide insight and guidance for continuing Caney Shale research. In the STACK play in the Anadarko basin (fig. 2; Wang et al., 2019) and the Wolfcamp Formation in the Permian basin (Kvale et al., 2020), silty carbonate (skeletal packstonegrainstone) and mudstone facies, when present in relatively thick intervals, show distinctively low and high gamma ray responses, respectively, which can be readily identified in logs to facilitate the mapping and prediction of these intervals in a wider scale. In addition, the vertical stacking of different facies with different log responses, as observed in the Mississippian-aged STACK play in north-central Oklahoma (Wang et al., 2019), can potentially be used to construct a hierarchical stratigraphic framework, which, when tied with gamma ray (GR) logs, can potentially help predict facies distribution (Wang et al., 2019). In the STACK play in north-central Oklahoma, the lower-GR, carbonaterich facies overlie the higher-GR, clay-rich facies at a wholecore scale (Wang et al., 2019). The poor condition of Caney core in this study makes it extremely difficult to derive the detailed vertical facies distribution at a whole-core scale. However, as we move forward in the project with higher quality Caney core and log data at a regional scale, such a tie among facies distribution, log pattern, reservoir quality, and stratigraphic framework as observed in the STACK play can assist in the characterization of the Caney facies and the prediction of reservoir quality distribution.

\section{Microporosity - Type and Geometry}

A variety of pore types have been documented in different mudrock units, and these pore types can play an important role in hydrocarbon storage and migration (Slatt and O'Brien, 2011). Different pore types and pore shapes are the result of a combination of depositional and diagenetic processes and tend to reflect matrix mineralogy, rock fabric and texture, and organic matter composition (Loucks et al., 2012). This relationship was observed in the Caney Shale samples analyzed for this study, in which the dominant pore type for each sample appears to reflect the rock fabric. For the silty carbonate samples, the dominant pore type is interparticle (fig. 14). The calcareous siltstone and mudstone samples are characterized by a combination of organic matter pores, interparticle pores, and intraparticle pores, with intraparticle pores likely forming the dominant pore type (figs. 13, 15). Loucks et al. (2012) compiled published pore type data from several geologic units illustrating the variety of dominant pore types that mudrock of different ages and geographic locations may exhibit. For example, units that are reported to have dominantly organic matter pores include the Barnett Shale, Marcellus Shale, and the Kimmeridge Clay, while other units such as the Eagle Ford Formation, Mancos Shale, and the Haynesville Shale are dominated by interparticle and intraparticle pores (Loucks et al., 2012). Based on the samples analyzed for this study, the Caney Shale appears to have mixed pore types as a whole.

\section{Effect of Mineralogy on Rock Geomechanical and Geochemical Properties}

The results from the core examined in this study indicate the carbonate-rich layers (silty carbonate) are sparsely distributed among mudstone, which is similar to the observations from Schad (2004) and Kamann (2006) (fig. 17). Variations in bulk mineralogy among these layers, such as carbonate, silica, and clay content, have a direct effect on rock geomechanical properties, such as rebound hardness (Wang and Grammer, 2018), elastic modulus, and creep compliance (Sone and Zoback, 2013). In addition, the distribution of inorganic and organic content as well as the spatial arrangement of minerals also affects the susceptibility to fracture initiation and propagation $(\mathrm{Du}$ and Radonjic, 2019; Du et al., 2020; Awejori et al., 2021; Awejori and Radonjic, 2021; Benge et al., 2021a, b).

One implication for the different rebound hardness values among different rock types is the potentially relevant differences in elastic parameters, which is

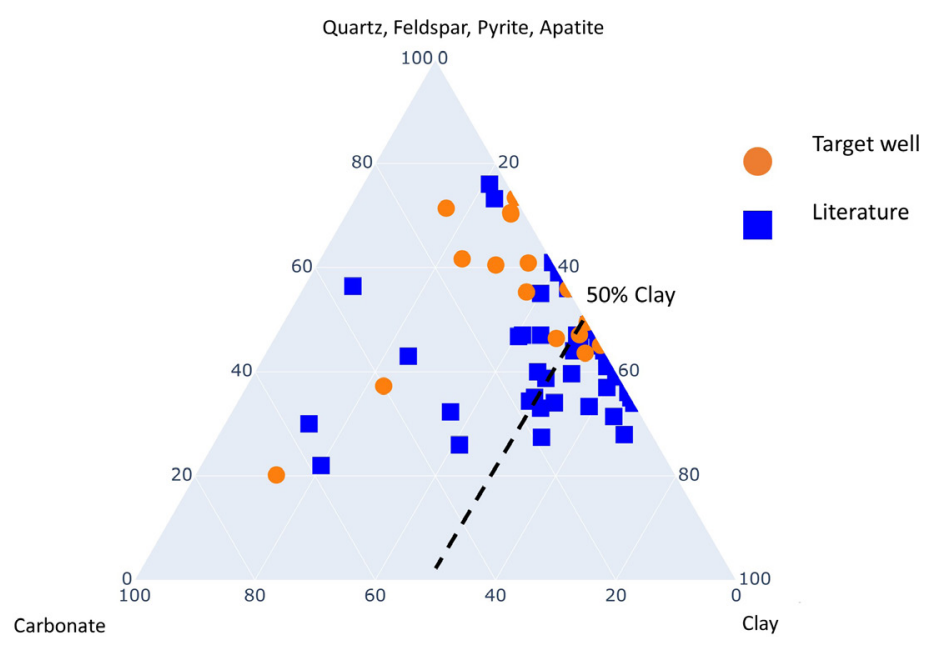

Figure 17. Mineralogical comparison between our target well and previous Caney literature (Schad, 2004; Kamann, 2006). Although data collected from literature are a mixture of different wells with various rock types, the generalized trends indicate that the Caney is dominantly high clay rock types interspersed with silty carbonate and carbonate-rich layers. This is similar to our observations of the core from the target well. 
observed in this study. As shown in table 3, a distinctive separation is present in Young's modulus among the three rock types, with mudstone, calcareous siltstone, and silty carbonate showing the lowest, intermediate, and highest Young's modulus, respectively. For calcareous siltstone and silty carbonate, this trend is also observed from their rebound hardness values (table 2). Although rebound hardness tests for the mudstone samples were not successful due to the crumbled nature of these samples, it is expected that mudstone, which contains the highest bulk clay content, likely exhibits the lowest rebound hardness values among the three rock types, as shown in the STACK play samples with similar rock types (in the range of 500 to $600 \mathrm{HLD}$; Wang and Grammer, 2018). In addition, the rebound hardness values of the siltstone and carbonate samples of this study show similar ranges with similar rock types in the STACK play, in which the siltstone samples commonly range from 600 to 700 HLD and carbonate samples commonly range from 700 to 800 HLD (Wang and Grammer, 2018). In this sense, the three Caney rock types observed in this study show distinctive separation in both rebound hardness and Young's modulus. As indicated by the heterogeneous distribution of these three rock types in the core of this study, such a pattern indicates a corresponding heterogeneity of rock mechanical properties, which can provide insights for drilling, completion, and production design. Specifically, silty carbonate, which shows the highest rebound hardness and Young's modulus values, may be favorable for creating and maintaining induced fractures to produce from the underlying and overlying organic-rich mudstone intervals. In addition, in the order from mudstone, calcareous siltstone, to silty carbonate, an overall positive trend between rebound hardness and Young's modulus can be inferred for the Caney samples of this study, indicating that rebound hardness may help estimate Young's modulus based on rock types. Further considering that these carbonate intervals are potential seal units and the enclosing mudstone and siltstone show higher reservoir potential (e.g., Wang et al., 2019), these carbonate deposits seem to show a key impact on reservoir distribution and production potential. Therefore, considering the variable distribution and geometry of the carbonate facies from a 3-D perspective (e.g., Wolfcamp Formation in the Permian basin; Kvale et al., 2020), integrating geomechanical data into the distribution of facies and petrophysical properties can provide additional insights for evaluating the reservoir and production potential at a wider scale. In this study, additional geomechanical analysis is necessary to further reveal the statistical relationship between rebound hardness and elastic properties for the Caney Shale.

Shale mineral composition not only affects geomechanical properties but also impacts potential scale precipitation as a result of mineral dissolution/ precipitation (Awejori et al., 2021) during well completion, stimulation, and production, when formation fluids are no longer in equilibrium with rock matrix due to invasion of fracturing fluids. In this study, our samples show distinctive scaling mineral distribution among the three rock types (fig. 18). Pyrite, apatite, and feldspar show extensive distribution in mudstone, while carbonate (calcite and dolomite) are concentrated in silty carbonate. Kan and Tomson (2012), Olajire (2015), and Kamal et al. (2018) summarize details related to common scaling minerals, and table 4 shows experimental conditions that trigger scaling. As far as scale is concerned, location-specific custom fracturing fluid designs compatible with the formation fluids would be most appropriate for the completion of these three rock types in the Caney.

\section{Connecting Geology, Geomechanics, Geochemistry, and} Engineering in the Caney Shale Toward Economically Optimized, Safe, and Environmentally Responsible Production

Development of Caney reservoirs focusing on the carbonate-rich zones (silty carbonate or calcareous siltstone) has shown initial success (Andrews, 2007). However, based on a first-order observation, the core of this study likely contains abundant mudstone. The clayrich mudstone challenges Caney well development as it has different rock mechanical properties, which could

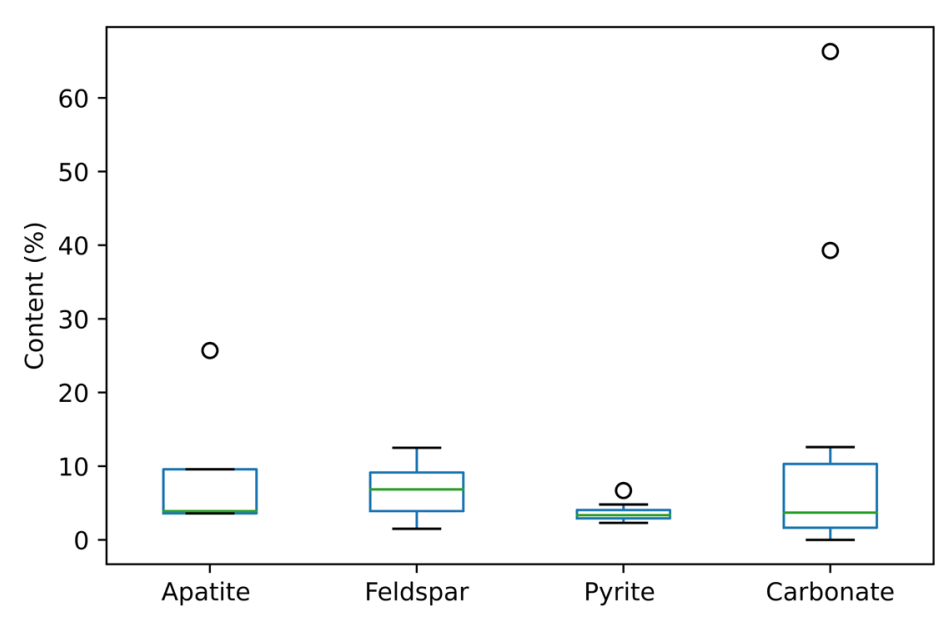

Figure 18. Scale-forming minerals in Caney samples including carbonates, pyrite, apatite, and feldspar. The existence of scaleforming minerals in all samples shows there is a potential scale issue in the Caney Shale. 
Multiscale Characterization of the Caney Shale - An Emerging Play in Oklahoma $\bullet$ Wang et al.

Table 4. Summary of experimental conditions for precipitating scaling minerals.

\begin{tabular}{llccccc}
\hline \hline & Mineral & Temperature & Pressure & pH & Flow rate & Potential scales \\
\hline Carbonate & (Zhang and Farquhar, 2001) & $90-180 \mathrm{C}^{\circ}$ & up to 1,450 psi & 6 & up to 1.3m/s & $\mathrm{CaCO}(\mathrm{FeCO} 3)$ \\
Pyrite & (Jew et al., 2017) & $80 \mathrm{C}^{\circ}$ & & 2 & static & $\mathrm{Fe}(\mathrm{OH}) 3$ \\
& (Li et al., 2018) & $80 \mathrm{C}^{\circ}$ & $1,117 \mathrm{psi}$ & 2 & & \\
Apatite & (Pilewski et al., 2019) & $100 \mathrm{C}^{\circ}$ & $2,500 \mathrm{psi}$ & $2.3-6.1$ & static & PO43- precipitate \\
Feldspar & (Chen et al., 2000) & $5-90 \mathrm{C}^{\circ}$ & & 2.9 & static & Al and Si precipitate \\
\hline
\end{tabular}

affect hydraulic fracture initialization, propagation, and closure (Yao, 2012; Alramahi and Sundberg, 2012). Existing tailored engineering approaches for clay-rich formations could have application to the Caney Shale. The Haynesville Shale is a well-studied and industry-developed formation with considerable heterogeneity and intervals of relatively high clay content (Cadotte et al., 2017). As a result, lessons learned from the Haynesville Shale could be important to constructing the development plan for the Caney Shale and include the following:

1. Completion design: Increased proppant mass per lateral foot is applied to counteract the proppant embedment (Cadotte et al., 2017; Katende et al., 2021), and the appropriate proppant size is important (Pope et al., 2009). The transition to hybrid fracturing fluid with higher fluid volume is associated with better production performance (Srinivasan et al., 2018).

2. Production strategy: Restricted rate flow-back programs with controlled drawdown is applied to reduce proppant embedment, fines migration, and proppant crushing (Thompson et al., 2011; Cadotte et al., 2017; Katende et al., 2021).

As demonstrated by fieldwide success in the clay-rich Haynesville Shale, economic development is possible as detailed laboratory information is formed into successful production knowledge. However, we need to keep in mind the uncertainty of the subsurface characterization. The heterogeneity identified in the Caney indicates that there is not one model that fits the real world. To illustrate the uncertainty and heterogeneity across the Caney Shale, we collected several representative shale compositions from published sources, as shown in fig. 19. The Barnett shows low clay content and is carbonate or quartz rich. The Haynesville is relatively clay- or carbonate-rich. In contrast, the Marcellus and Fayetteville shales show a wide range of compositions. Similar to our Caney observations, rocks with different mineralogy coexist in each formation, which adds to the immense heterogeneity.
Often, shale development is based on ductility or brittleness of the different facies with most of the development focused on the brittle shale (Benge et al., 2021a, b). However, there is no clear divide between ductile and brittle categories. The ductile and brittle distinction is caused by multiple factors at different scales. At a microscale, the pore structure, rock fabric, and mineralogy play important roles as shown in the previous section. At the macroscale, these factors include rock types, natural fractures, and bedding. Because of multiscale heterogeneity and uncertainty, it is difficult to predict where the ductile and brittle transition happens. Therefore, geological knowledge is important for the success of field development, and the integration of multiscale techniques is essential to understand geological properties.

Since this study is preliminary in nature, our future work in Caney Shale field development includes detailed study of nanoporosity and nanostructure as well as engineered fractures in a newly drilled well with whole core. A successful integration of geologic characterization and engineering is essential in shale development. In addition, engineering approaches during development need to be tailored to the formation, based on the understanding of geology. Earlier engineering approaches have included proppant volume, type and size studies, proppant embedment control, hybrid fracturing fluids, and controlled drawdowns. Integrating geological information into the early stages of drilling to production development can help tap resources that were previously poorly accessed.

\section{CONCLUSIONS}

Successful shale well development requires a multidisciplinary integration of geological, geochemical, geomechanical, and engineering methods. This multiscale and multiprocess approach to rock characterization is critical to understanding the entire life cycle of a play and the effect of applying optimal engineering technology. 


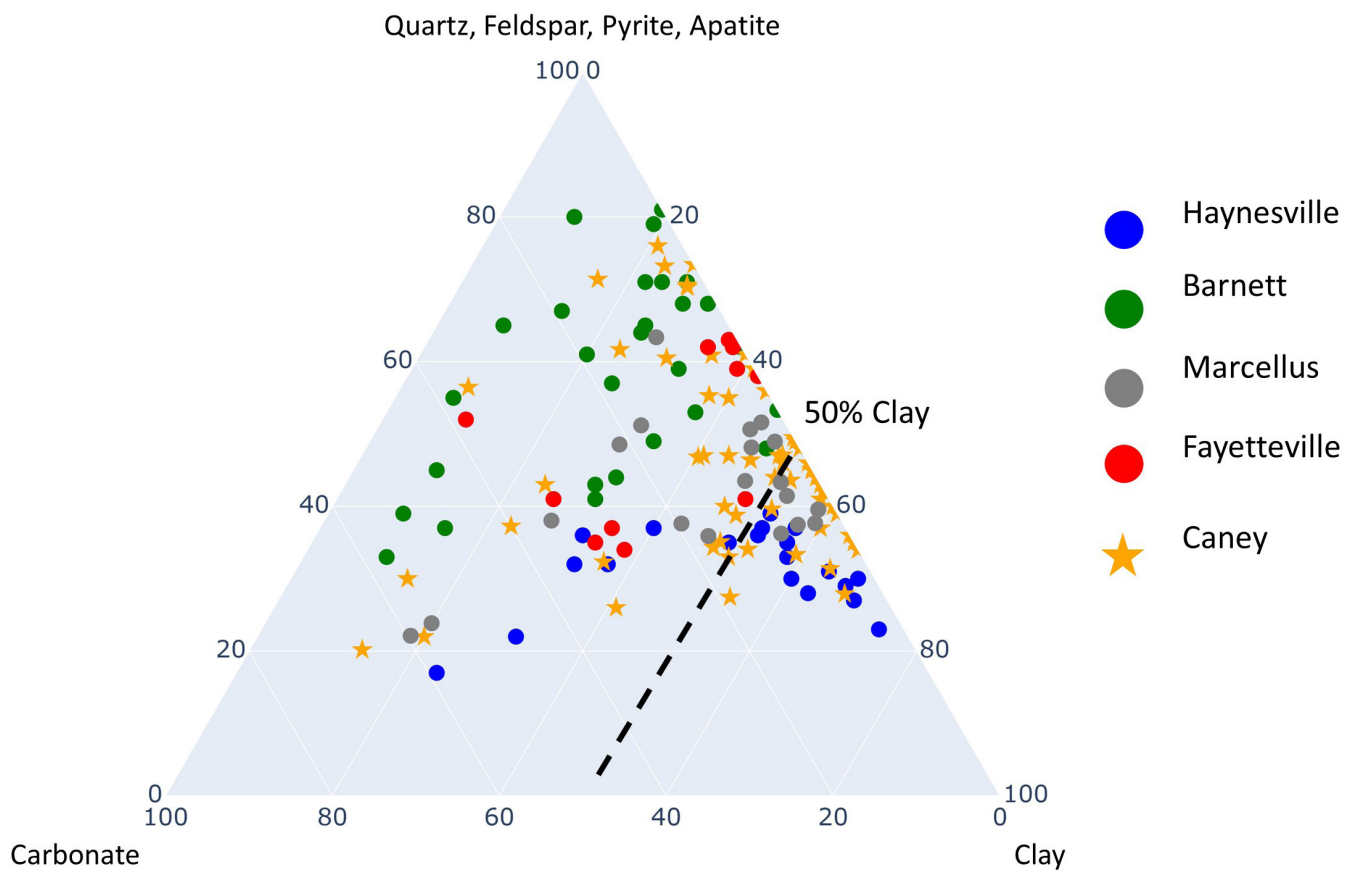

Figure 19. Comparison of Haynesville, Barnett, Marcellus, Fayetteville, and Caney shales. Caney data include our measurements and data collected from Schad (2004) and Kamann (2006). Haynesville data are from Kuila (2013). Barnett data are from Loucks and Ruppel (2007). Marcellus data are from Fortson (2012) and Staub (2014). Fayetteville data are from Briggs (2014), Jansen (2014), and Deville et al. (2011). We used 50\% clay content as a reference for comparison (Al Duhailan et al., 2015). As data were collected from published sources, they might not capture the full range of variability for these shales.

Using the proposed integrated approach, we classified three rock types within the Caney Shale: silty carbonate, calcareous siltstone, and mudstone. Each of the rock types has distinctive macro- and microscale structures, mineralogy, and geomechanical properties, which will influence fluid flow and ultimate production of hydrocarbons.

1. Silty carbonate and calcareous siltstone show distinctively lower clay content compared with mudstone. Carbonate minerals are concentrated as layers in core, and carbonate-rich layers (silty carbonate) are interspersed within mudstone.

2. These three rock types show distinctive pore structures. The silty carbonate samples contain mostly interparticle pores. The calcareous siltstone and silty mudstone samples contain a combination of organic matter pores and interparticle pores. The mudstone contains abundant organic matter pores and the calcareous siltstone and silty carbonate contain mostly interparticle pores. Porosity in all three identified rock types is mostly contributed by micro- and nanometerscale interparticle and intraparticle pores.

3. The silty carbonate layers in the Caney Shale have distinctively higher values of rebound hardness and Young's modulus. These carbonate-rich layers can be targeted for enhanced fracture propagation and production. Therefore, integration of geomechanical data with the distribution of facies and petrophysical properties from a 3-D perspective can provide insights for evaluating the reservoir and production potential. This study focuses on the characterization of the Caney Shale using limited samples from one core. Limited by the poor condition of the core and lack of logs from this well, it is difficult to tie the core with wireline logs to extrapolate the core-based interpretation into uncored wells at a regional scale. However, we will extend our work to a newly drilled Caney well with a more complete dataset. Detailed localized and basinwide characterization will be conducted in subsequent studies.

\section{ACKNOWLEDGMENTS}

This study was made possible by DOE Award DEFE0031776 from the Office of Fossil Energy's Oil and Natural Gas Program, U.S. Department of Energy. The authors appreciate the guidance of Joseph Renk, Technical Project Officer, National Energy Technology Laboratory. The authors would like to thank Lisa Whitworth and Brent Johnson of Oklahoma State University Microscopy Laboratory and Adam Haecker from Continental Resources for providing Caney well production histories. The 
authors also wish to acknowledge Christine Doughty from Lawrence Berkeley National Laboratory for sharing published literature and to thank Pam Reynolds for her proofreading of this paper. Lastly, the authors would like to acknowledge the support from the Oklahoma State University Barrier and Geomimicry Laboratory.

\section{REFERENCES}

Al Duhailan, M. A., Sonnenberg, S. A., and Longman, M., 2015, Analyzing beef fractures: Genesis and relationship with organic-rich shale facies: Unconventional Resources Technology Conference, San Antonio, Texas, 20-22 July.

Alramahi, B., and Sundberg, M., 2012, Proppant embedment and conductivity of hydraulic fractures in shales: Proceedings, 46th U.S. Rock Mechanics / Geomechanics Symposium, Chicago, Illinois, 24-27 June.

Andrews, R. D., 2007, Stratigraphy, production, and reservoir characteristics of the Caney Shale in southern Oklahoma: Shale Shaker, v. 58, p. 9-25

Awejori, G., and Radonjic, M., 2021, Review of geochemical and geo-mechanical impact of formation clay-fluid interactions: Focus on hydraulic fracturing: IntechOpen, p. 1-23.

Awejori, G. A., Luo, G., Grider, C., Katende, A., Radonjic, M., Doughty, C., Spycher, N., Paronish, T., O'Connell, L., and Rihn, A., 2021, Fracturing fluid-induced mineralogy changes and impact on elastic properties for the Caney Shale, Oklahoma: American Rock Mechanics Association, June 2021.

Bai, B., Elgmati, M., Zhang, H., and Wei, M., 2013, Rock characterization of Fayetteville Shale gas plays: Fuel, v.105, p. 645-652.

Benge, M., Lu, Y., Jones, J., Bunger, A. P., Haecker, A., Rihn, A., Crandall, D., Luo, G., and Radonjic, M., 2021a, Mechanical properties of nominally ductile and brittle zones within the Caney Shale Formation: Paper presented in the Proceedings of the 55th U.S. Rock Mechanics / Geomechanics Symposium, The Woodlands, Houston, Texas, 20-23 June.

Benge, M., Lu, Y., Jones, J., Katende, A., Rutqvist, J., Doughty, C., Crandall, D., Haecker, A., King, G., Renk, J., Radonjic, M., and Bunger, A. P., 2021b, Connecting geomechanical properties with potential for proppant embedment and production decline for the emerging Caney Shale, Oklahoma: Paper presented at the Unconventional Resources Technology Conference (URTeC), Houston, Texas, 26-28 July.

Briggs, K., 2014, The influence of vertical location on hydraulic fracture conductivity in the Fayetteville Shale: M.S. thesis, Texas A\&M University, College Station, Texas, 83 p.

Cadotte, R., Whitsett, A., Sorrell, M., and Hunter, B., 2017, Modern completion optimization in the Haynesville Shale: Society of Petroleum Engineers (SPE) Annual Technical Conference and Exhibition, San Antonio, Texas, 9-11 October.

Cardott, B. J., 2017, Oklahoma shale resource plays: Oklahoma Geology Notes, v. 76, no. 2, p. 21-30.

Chen, Y., Brantley, S. L., and Ilton, E. S., 2000, X-ray photoelectron spectroscopic measurement of the temperature dependence of leaching of cations from the albite surface: Chemical Geology, v. 163, no. 1-4, p. 115-128.
Deville, J. P., Fritz, B., and Jarrett, M., 2011, Development of waterbased drilling fluids customized for shale reservoirs: Society of Petroleum Engineers (SPE) Drilling \& Completion, v. 26, no. 04, p. 484-491.

Du, H., and Radonjic, M., 2019, The mechanism of fracture initiation in shale rocks: Pottsville cap-rock-shale vs. Marcellus unconventional reservoir-shale: $53^{\text {rd }}$ American Rock Mechanics / Geomechanics Symposium, New York City, 23-26 June.

Du, H., Radonjic, M., and Chen, Y., 2020, Microstructure and micro-geomechanics evaluation of Pottsville and Marcellus shales: Journal of Petroleum Science and Engineering, v. 195, 107876. https: / / doi.org/10.1016/j.petrol.2020.107876

Eberli, G. P., Weger, R. J., Tenaglia, M., Rueda, L., Rodriguez, L., Zeller, M., McNeill, D., Murray, S., and Swart, P. K., 2017, The unconventional play in the Neuquén basin, Argentina Insights from the outcrop for the subsurface: Unconventional Resources Technology Conference (URTeC), Austin, Texas, 24-26 July.

Evans, M., 2016, Unconventional hydrocarbons and the US technology revolution; in R. Grafton, I. Cronshaw, and M. Moore, Eds., Risks, Rewards and Regulation of Unconventional Gas: A Global Perspective: Cambridge, Cambridge University Press, p. 59-91. DOI:10.1017/9781316341209.006

Fishman, N. S., Ellis, G. S., Boehlke, A. R., Paxton, S. T., and Egenhoff, S. O., 2013, Gas storage in the Upper DevonianLower Mississippian Woodford Shale, Arbuckle Mountains, Oklahoma: How much of a role do chert beds play? in J. Chatellier and D. M. Jarvie, eds., Critical Assessment of Shale Resource Plays: American Association of Petroleum Geologists (AAPG) Memoir, v. 103, p. 81-107.

Fortson, L., 2012, Geochemical and spatial investigation of uranium in the Marcellus Shale: M.S. thesis, State University of New York at Buffalo, 61 p.

Gale, J. F., Laubach, S. E., Olson, J. E., Eichhubl, P., and Fall, A., 2014, Natural fractures in shale: A review and new observations: American Association of Petroleum Geologists (AAPG) Bulletin, v. 98, p. 2,165-2,216.

Grammer, G. M., Gregg, J. M., Puckette, J., Jaiswal, P., Mazzullo, S. J., Pranter, M. J., and Goldstein, R. H., eds., 2019, Mississippian Reservoirs of the Midcontinent: American Association of Petroleum Geologists (AAPG) Memoir, v. 122, $560 \mathrm{p}$.

Houseknecht, D. W., Coleman, Jr., J. L., Milici, R. C., Garrity, C. P., Rouse, W. A., Fulk, B. R., Paxton, S. T., Abbott, M. M., Mars, J. L., Cook, T. A., and Schenk, C. J., 2010, Assessment of undiscovered natural gas resources of the Arkoma basin province and geologically related areas: U.S. Geological Survey Fact Sheet 2010-3043, 4 p.

Jansen, T. A., 2014, The effect of rock properties on hydraulic fracture conductivity in the Eagle Ford and Fayetteville Shales: M.S. thesis, Texas A\&M University, College Station, Texas, $114 \mathrm{p}$.

Jew, A. D., Dustin, M. K., Harrison, A. L., Joe-Wong, C. M., Thomas, D. L., Maher, K., Brown Jr., G. E., and Bargar, J. R., 2017, Impact of organics and carbonates on the oxidation and precipitation of iron during hydraulic fracturing of shale: 
Energy \& Fuels, v. 31, no. 4, p. 3,643-3,658. https:/ / doi. org/10.1021/acs.energyfuels.6b03220

Kamal, M. S., Hussein, I., Mahmoud, M., Sultan, A. S., and Saad, M. A., 2018, Oilfield scale formation and chemical removal: A review: Journal of Petroleum Science and Engineering, v. 171, p. 127-139. https: / / doi.org/10.1016/j.petrol.2018.07.037

Kamann, P. J., 2006, Surface-to-subsurface correlation and lithostratigraphic framework of the Caney Shale (including the "Mayes" Formation) in Atoka, Coal, Hughes, Johnston, Pittsburg, and Pontotoc counties, Oklahoma: M.S. thesis, Oklahoma State University, Stillwater, Oklahoma, 259 p.

Kan, A., and Tomson, M., 2012, Scale prediction for oil and gas production: Society of Petroleum Engineers (SPE) Journal, v. 17, no. 02, p. 362-378. https:/ / doi.org/10.2118/132237-PA

Katende, A., O'Connell, L., Rich, A., Rutqvist, J., and Radonjic, M., 2021, A comprehensive review of proppant embedment in shale reservoirs: Experimentation, modeling and future prospects: Journal of Natural Gas Science and Engineering, in press, $29 \mathrm{p}$.

King, G. E., 2010, Thirty years of gas shale fracturing: What have we learned? Society of Petroleum Engineers (SPE) Annual Technical Conference and Exhibition, Florence, Italy, 19-22 September.

Ko, L. T., Loucks, R. G., Zhang, T., Ruppel, S. C., and Shao, D., 2016, Pore and pore network evolution of upper Cretaceous Boquillas (Eagle Ford-equivalent) mudrocks: Results from gold tube pyrolysis experiments: American Association of Petroleum Geologists (AAPG) Bulletin, v. 100, no. 11, p. $1,693-1,722$.

Kompatscher, M., 2004, Equotip — rebound hardness testing after D. Leeb: Proceedings, Conference on Hardness Measurements Theory and Application in Laboratories and Industries, 1, 1-12.

Kuila, U., 2013, Measurement and interpretation of porosity and pore-size distribution in mudrocks: The hole story of shales: Ph.D. dissertation, Colorado School of Mines, Golden, Colorado, $238 \mathrm{p}$.

Kvale, E. P., Bowie, C. M., Flenthrope, C., Mace, C., Parrish, J. M., Price, B., Anderson, S., and DiMichele, W. A., 2020, Facies variability within a mixed carbonate-siliciclastic sea-floor fan (upper Wolfcamp Formation, Permian, Delaware basin, New Mexico): American Association of Petroleum Geologists (AAPG) Bulletin, v. 104, p. 525-563.

Leeb, D., 1979, Dynamic hardness testing of metallic materials: NDT International, v. 12, no. 6, p. 274-278.

Li, Q., Jew, A. D., Kiss, A. M., Kohli, A., Alalli, A., Kovscek, A. R., Zoback, M. D., Cercone, D., Maher, K., Brown Jr., G. E., and Bargar, J. R., 2018, Imaging pyrite oxidation and barite precipitation in gas and oil shales: Unconventional Resources Technology Conference (URTeC), Houston, Texas, 23-25 July.

Lohr, C. D., Valentine, B. J., Hackley, P. C., and Dulong, F. T., 2020, Characterization of the unconventional Tuscaloosa marine shale reservoir in southwestern Mississippi, USA: Insights from optical and SEM petrography: Marine and Petroleum Geology, v. 121, 104580. https: / / doi.org/10.1016/j.

marpetgeo.2020.104580
Loucks, R. G., Reed, R. M., Ruppel, S. C., and Hammes, U., 2012 , Spectrum of pore types and networks in mudrocks and a descriptive classification for matrix-related mudrock pores: American Association of Petroleum Geologists (AAPG) Bulletin, v. 96, no. 6, p. 1,071-1,098. https: / / doi. org / 10.1306/08171111061

Loucks, R. G., and Ruppel, S. C., 2007, Mississippian Barnett Shale: Lithofacies and depositional setting of a deep-water shale-gas succession in the Fort Worth basin, Texas: American Association of Petroleum Geologists (AAPG) Bulletin, v. 91, no. 4, p. 579-601. https: / / doi.org/10.1306/11020606059

Medina, C. R., Mastalerz, M., Lahann, R. W., and Rupp, J. A., 2020, A novel multi-technique approach used in the petrophysical characterization of the Maquoketa Group (Ordovician) in the southeastern portion of the Illinois basin: Implications for seal efficiency for the geologic sequestration of CO2: International Journal of Greenhouse Gas Control, v. 93, p. 102,883.

Mullen, J., Lowry, J. C., and Nwabuoku, K. C., 2010, Lessons learned developing the Eagle Ford Shale: Tight Gas Completions Conference, San Antonio, Texas, 2-3 November.

Northcutt, R. A., and Campbell, J. A., 1996, Geologic provinces of Oklahoma: Transactions of the 1995 AAPG Mid-Continent Section Meeting, p. 128-134.

Olabode, A., Radonjic, M., 2014, Characterization of shale caprock nanopores in geologic $\mathrm{CO}_{2}$ containment: Journal of Environmental \& Engineering Geoscience, v. 20, no. 2. https: / / doi.org/10.2113/gseegeosci.20.4.361

Olajire, A. A., 2015, A review of oilfield scale management technology for oil and gas production: Journal of Petroleum Science and Engineering, v. 135, p. 723-737. https: / / doi. org / 10.1016/j.petrol.2015.09.011

Pilewski, J., Sharma, S., Agrawal, V., Hakala, J. A., and Stuckman, M. Y., 2019, Effect of maturity and mineralogy on fluid-rock reactions in the Marcellus Shale: Environmental Science: Processes \& Impacts, v. 21, no. 5, p. 845-855. https: / / doi. org / 10.1039/C8EM00452H

Pope, C., Peters, B., Benton, T., and Palisch, T., 2009, Haynesville Shale - One operator's approach to well completions in this evolving play: Society of Petroleum Engineers (SPE) Annual Technical Conference and Exhibition. New Orleans, Louisiana, 4-7 October.

Radonjic, M., Luo, G., Wang, Y., Achang, M., Cains, J., Katende, A., Puckette, J., Grammer, G. M., and King, G. E., 2020, Integrated microstructural characterization of Caney Shale, OK: Unconventional Resources Technology Conference (URTeC), Austin, Texas, 20-22 July.

Saif, T., Lin, Q., Butcher, A. R., Bijeljic, B., and Blunt, M. J., 2017, Multi-scale multi-dimensional microstructure imaging of oil shale pyrolysis using X-ray micro-tomography, automated ultra-high resolution SEM, MAPS mineralogy and FIB-SEM: Applied Energy, v. 202, p. 628-647.

Sarg, J. F., 2012, The Bakken - An unconventional petroleum and reservoir system: Final scientific/technical report, DOE Award No.: DE-NT0005672, United States Department of Energy Office of Fossil Energy, National Energy Technology Laboratory, $65 \mathrm{p}$. 
Schad, S. T., 2004, Hydrocarbon potential of the Caney Shale in southeastern Oklahoma: M.S. thesis, University of Tulsa, Oklahoma, 576 p.

Slatt, R. M., and O'Brien, N. R., 2011, Pore types in the Barnett and Woodford gas shales: Contribution to understanding gas storage and migration pathways in fine-grained rocks: American Association of Petroleum Geologists (AAPG) Bulletin, v. 95, no. 12, p. 2,017-2,030. https: / / doi. org / 10.1306/ 03301110145

Slatt, R. M., Philp, P. R., Abousleiman, Y., Singh, P., Perez, R., Portas, R., Marfurt, K. J., Madrid-Arroyo, S., O’Brien, N., Eslinger, E., and Baruch, E. T., 2012, Pore-to-regional-scale integrated characterization workflow for unconventional gas shales; in J. A. Breyer, ed., Shale Reservoirs-Giant Resources for the 21st Century: American Association of Petroleum Geologists (AAPG) Memoir 97, p. 127-150.

Sone, H., and Zoback, M. D., 2013, Mechanical properties of shalegas reservoir rocks-Part 2: Ductile creep, brittle strength, and their relation to the elastic modulus: Geophysics, v. 78, no. 5, p. D393-D402. https:/ / doi.org/10.1190/geo2013-0051.1

Srinivasan, K., Ajisafe, F., Alimahomed, F., Panjaitan, M., Makarychev-Mikhailov, S., and Mackay, B., 2018, Is there anything called too much proppant? Society of Petroleum Engineers (SPE) Liquids-Rich Basins Conference-North America, Midland, Texas, 5-6 September.

Staub, P., 2014, Clay mineralogy of the Marcellus and Utica Shales: Implications for fluid development via cation exchange: M.S. thesis, State University of New York at Buffalo.

Thompson, J., Fan, L., and Grant, D., 2011, An overview of horizontal-well completions in the Haynesville Shale: Journal of Canadian Petroleum Technology, v. 50, no. 06, p. 22-35. https: / / doi.org/10.2118/136875-PA

Vanden Berg, B., and Grammer, G. M., 2016, 2-D pore architecture characterization of a carbonate mudrock reservor: Insights from the Mid-Continent "Mississippi Lime"; in T. Olson, ed., Imaging Unconventional Reservoir Pore Systems: AAPG Memoir, v. 112, p. 185-232. DOI:10.1306/13592022M1123698

Vanden Berg, B., LeBlanc, S., and Grammer, G. M., 2019, Integrated reservoir characterization to provide insight into porosity and permeability in a mixed carbonate-siliciclastic reservoir; in G. M. Grammer, J. M. Gregg, J. Puckette, P.
Jaiswal, S. J. Mazzullo, M. J. Pranter, and R. H. Goldstein, eds., Mississippian Reservoirs of the Midcontinent: American Association of Petroleum Geologists (AAPG) Memoir, v. 122, p. 227-270. https: / / doi.org/10.1306/13632150M1163698

Wang, Y., Cains, J., Grammer, G. M., Pashin, J. C., and Puckette, J., 2021, Facies architecture and reservoir characteristics of the Caney Shale, Ardmore basin, Southern Oklahoma, USA: 2021 AAPG Annual Conference and Exhibition abstract, accepted for poster presentation.

Wang, Y., and Grammer, G. M., 2018, Rebound hardness: Relationship to facies, mineralogy, natural fractures, reservoir quality, and rock mechanical properties, the "Mississippian Limestone" play, north-central Oklahoma, USA: 2018 American Rock Mechanics Association (ARMA) Symposium, Seattle, Washington, 17-20.

Wang, Y., Thompson, T., and Grammer, G. M., 2019, Fracture characterization and prediction in unconventional reservoirs of the "Mississippian Limestone," north-central Oklahoma, USA; in G. M. Grammer, J. M. Gregg, J. Puckette, P. Jaiswal, S. J. Mazzullo, M. J. Pranter, and R. H. Goldstein, eds., Mississippian Reservoirs of the Midcontinent: American Association of Petroleum Geologists (AAPG) Memoir, v. 122, p. 271-299. https: / / doi.org/10.1306/13632151M1163789

Weber, J. L., 1994, A geochemical study of crude oils and possible source rocks in the Ouachita tectonic province and nearby areas, Southeast Oklahoma: Oklahoma Geological Survey, University of Oklahoma, special publication 94-2, $32 \mathrm{p}$.

Yan, C., Luo, G., and Ehlig-Economides, C. A., 2015, Systematic study of Bakken well performance over three wellcompletion-design eras: Journal of Canadian Petroleum Technology, v. 54, no. 02, p. 95-106. https: / / doi. org / 10.2118/171566-PA

Yao, Y., 2012, Linear elastic and cohesive fracture analysis to model hydraulic fracture in brittle and ductile rocks: Rock Mechanics and Rock Engineering, v. 45, no. 3, p. 375-387. https: / / doi.org/10.1007/ s00603-011-0211-0

Zhang, Y., and Farquhar, R., 2001, Laboratory determination of calcium carbonate scaling rates for oilfield wellbore environments: International Symposium on Oilfield Scale, Society of Petroleum Engineers, Aberdeen, United Kingdom, 30-31 January. 


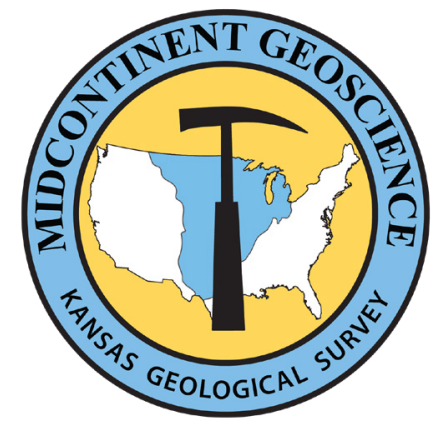

\title{
Midcontinent Geoscience • Volume 2・September 2021 Tony Layzell — Editor
}

\author{
Section Editor - Franek Hasiuk \\ Technical Editor — Julie Tollefson
}

Suggested citation: Wang, Y., Luo, G., Achang, M., Cains, J., Wethington, C., Katende, A., Grammer, G. M., Puckette, J., Pashin, J., Castagna, M., Chan, H., King, G. E., and Radonjic, M., Multiscale characterization of the Caney Shale An emerging play in Oklahoma: Midcontinent Geoscience, v. 2, p. 33-53.

Midcontinent Geoscience is an open-access, peer-reviewed journal of the Kansas Geological Survey. The journal publishes original research on a broad array of geoscience topics, with an emphasis on the midcontinent region of the United States, including the Great Plains and Central Lowland provinces.

Submission information: https:/ /journals.ku.edu/mg/about/submissions

Kansas Geological Survey 1930 Constant Avenue The University of Kansas Lawrence, KS 66047-3724 785.864.3965

http://www.kgs.ku.edu/

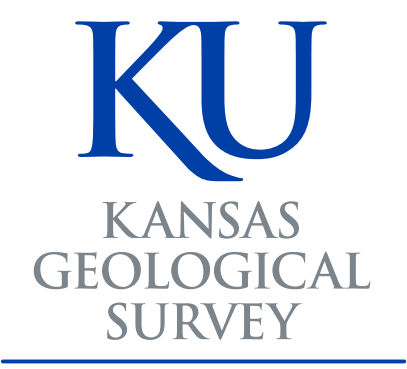

